\title{
Hypothalamic Tumor Necrosis Factor- $\alpha$ Converting Enzyme Mediates Excitatory Amino Acid-Dependent Neuron-to-Glia Signaling in the Neuroendocrine Brain
}

\author{
Alejandro Lomniczi, Anda Cornea, Maria E. Costa, and Sergio R. Ojeda \\ Division of Neuroscience, Oregon National Primate Research Center/Oregon Health and Science University, Beaverton, Oregon 97006
}

\begin{abstract}
Glial erbB1 receptors play a significant role in the hypothalamic control of female puberty. Activation of these receptors by transforming growth factor $\alpha$ (TGF $\alpha$ ) results in production of prostaglandin $\mathrm{E}_{2}$, which then stimulates luteinizing hormone releasing hormone (LHRH) neurons to secrete LHRH, the neuropeptide controlling sexual development. Glutamatergic neurons set in motion this glia-toneuron signaling pathway by transactivating erbB1 receptors via coactivation of AMPA receptors (AMPARs) and metabotropic glutamate receptors (mGluRs). Because the metalloproteinase tumor necrosis factor $\alpha$ converting enzyme (TACE) releases TGF $\alpha$ from its transmembrane precursor before TGF $\alpha$ can bind to erbB1 receptors, we sought to determine whether TACE is required for excitatory amino acids to activate the TGF $\alpha$ - erbB1 signaling module in hypothalamic astrocytes, and thus facilitate the advent of puberty. Coactivation of astrocytic AMPARs and mGluRs caused extracellular $\mathrm{Ca}^{2+}$ influx, a $\mathrm{Ca}^{2+}$ /protein kinase C-dependent increase in TACE-like activity, and enhanced release of TGF $\alpha$. Within the hypothalamus, TACE is most abundantly expressed in astrocytes of the median eminence (ME), and its enzymatic activity increases selectively in this region at the time of the first preovulatory surge of gonadotropins. ME explants respond to stimulation of AMPARs and mGluRs with LHRH release, and this response is prevented by blocking TACE activity. In vivo inhibition of TACE activity targeted to the ME delayed the age at first ovulation, indicating that ME-specific changes in TACE activity are required for the normal timing of puberty. These results suggest that TACE is a component of the neuron-to-glia signaling process used by glutamatergic neurons to control female sexual development.
\end{abstract}

Key words: TGF $\alpha$; astrocytes; ectodomain shedding; proteolytic cleavage; female puberty; hypothalamus

\section{Introduction}

The initiation of mammalian puberty requires an increase in hypothalamic luteinizing hormone release hormone (LHRH) secretion (Ojeda and Terasawa, 2002). LHRH secretion is subjected to both neuron-to-neuron (Kordon et al., 1994) and glia-toneuron (Ojeda et al., 2000) regulatory inputs. A significant part of the latter control is exerted at the level of the median eminence (ME), a circumventricular organ (McKinley et al., 1990) devoid of neuronal cell bodies but rich in astrocytes (Kobayashi et al., 1972; Rützel and Schiebler, 1980) and modified ependymoglial cells known as tanycytes (Knowles, 1972; Kozlowski and Coates, 1985). Within the ME, glial-neuronal contacts (Kordon et al., 1994; Silverman et al., 1994) provide the anatomical substrate for the operation of several glia-to-neuron signaling pathways controlling LHRH release (Garcia-Segura et al., 1996; Galbiati et al., 2003; Ojeda et al., 2003).

A key trans-synaptic input required for the activation of LHRH neurons at puberty is provided by glutamatergic neurons

Received July 15, 2005; revised 0ct. 28, 2005; accepted Nov. 3, 2005.

This work was supported by National Institutes of Health Grants HD25123, RR00163, and U54 HD18185 through a cooperative agreement as part of the Specialized Cooperative Center's Program in Reproduction Research.

Correspondence should be addressed to Alejandro Lomniczi or Sergio R. 0jeda, Division of Neuroscience, Oregon National Primate Research Center, 505 Northwest 185th Avenue, Beaverton, OR 97006. E-mail: ojedas@ohsu.edu. DOI:10.1523/JNEUROSCI.2939-05.2006

Copyright $\odot 2006$ Society for Neuroscience $\quad 0270-6474 / 06 / 260051-12 \$ 15.00 / 0$
(Plant et al., 1989; Urbanski and Ojeda, 1990). They act via NMDA and AMPA/kainate receptors expressed in both LHRH neurons and interneurons connected to the LHRH neuronal network (Gore et al., 1996; Eyigor and Jennes, 1997; Eyigor and Jennes, 2000; Ottem et al., 2002). Notwithstanding the importance of this trans-synaptic control, it recently became evident that glutamatergic neurons can also control astrocytic function, and therefore LHRH release, via facilitation of erbB-dependent glia-to-neuron signaling pathways (Dziedzic et al., 2003). One of these pathways is initiated by transforming growth factor $\alpha$ (TGF $\alpha$ ), which in both hypothalamic astrocytes (Ma et al., 1994c) and tanycytes (Prevot et al., 2003b) signals via erbB1 receptors. The integrity of erbB1 signaling is important for the timing of puberty, because female sexual development is delayed in mice carrying mutated erbB1 receptors or a combined erbB1/ erbB4 receptor defect (Apostolakis et al., 2000; Prevot et al., 2003a, 2005).

Glutamate activates both erbB1- and erbB4-mediated pathways by concomitantly stimulating AMPA receptors (AMPARs) and metabotropic glutamate receptors (mGluRs) located on astroglial cells (Dziedzic et al., 2003). Stimulation of these glutamate receptors results in recruitment of erbB1 and erbB4 receptors and their ligands to the glial cell membrane and causes phosphorylation of both receptors. This transactivation is prevented by inhibition of metalloproteinase (MMP) activity (Dz- 
iedzic et al., 2003). Because MMP-mediated processing of membrane-bound erbB ligands is required for the liganddependent activation of erbB receptors between cells in contact (Dong et al., 1999; Prenzel et al., 1999; Gschwind et al., 2001), AMPAR/mGluR-dependent transactivation of astrocytic erbB receptors may involve ectodomain shedding of erbB ligands.

We now report that tumor necrosis factor $\alpha$ converting enzyme (TACE), a member of the disintegrin and metalloproteases (ADAMs) family of metalloproteases (Schlöndorff and Blobel, 1999), and the major metalloproteinase mediating TGF $\alpha$ ectodomain processing (Peschon et al., 1998; Sahin et al., 2004), is required for AMPAR/mGluR-dependent activation of TGF $\alpha$ release from hypothalamic astrocytes and for LHRH release. We also show that astrocytes of the ME are rich in TACE and that blockade of TACE activity targeted to the ME delays the onset of female puberty. These findings suggest that TACE-mediated ectodomain shedding of erbB ligands, epitomized by TGF $\alpha$, is a key component of the neuron-to-glia signaling mechanism used by excitatory amino acids to facilitate the advent of female puberty.

\section{Materials and Methods}

Animals. Immature Sprague Dawley rats were obtained from Harlan Sprague Dawley (Indianapolis, IN). They were housed in a room with controlled photoperiod (14/10 h light/dark cycle) and temperature (23$25^{\circ} \mathrm{C}$ ) and were allowed access to tap water and pelleted rat chow ad libitum. Animals younger than $21 \mathrm{~d}$ of age were housed with their mothers.

Tissue dissection. For measurement of TACE mRNA or enzyme activity, the hypothalamus was extracted as a whole including the region above the optic chiasm, which contains the preoptic area and suprachiasmatic nucleus, and the medial basal hypothalamus $(\mathrm{MBH})$, which contains the ME, arcuate nucleus, and ventromedial nucleus. The lateral basal hypothalamus (between the ME and the hypothalamic sulci) was dissected away from the ME and was termed $\mathrm{MBH}(-)$. After collection, the tissues were frozen on dry ice and stored at $-85^{\circ} \mathrm{C}$ until RNA or protein extraction.

For experiments involving incubation of ME fragments with excitatory amino acid receptor agonists (see below), the ME was microdissected under a stereomicroscope as described previously (Negro-Vilar et al., 1979).

Cell culture. Astrocytes were isolated from the hypothalami of 1- to 2-d-old rats and cultured as described previously (Ma et al., 1994a, 1999). After a growth period of $8-10 \mathrm{~d}$ in $75 \mathrm{~cm}$ culture flasks containing DMEM/F-12 medium supplemented with $10 \%$ calf serum (HyClone, Logan, UT), astrocytes were isolated from other cell types by overnight shaking at $250 \mathrm{rpm}$ and replated on either $10 \mathrm{~cm}$ dishes $\left(2 \times 10^{6}\right.$ cells per dish) for TACE activity or 12-well plates at 300,000 cells per well for TGF $\alpha$ release experiments. After reaching $80-90 \%$ confluence, the medium was replaced with a serum-free, astrocyte-defined medium (ADM) consisting of DMEM devoid of phenol red, supplemented with $2 \mathrm{mM}$ L-glutamine, $15 \mathrm{~mm}$ HEPES, $5 \mu \mathrm{g} / \mathrm{ml}$ insulin, and $100 \mu \mathrm{M}$ putrescine (Ma et al., 1999). The cells were exposed $4 \mathrm{~d}$ later for the experiments to determine the effect of the excitatory amino acid agonists AMPA (100 $\mu \mathrm{M})$ and tACPD $[(1 S, 3 R)$ trans-1-aminocyclopentane-1,3-dicarboxylic acid] $(100 \mu \mathrm{M})$ (Sigma, St. Louis, MO) or the selective TACE inhibitor (Arribas et al., 1996; Karkkainen et al., 2000) TAPI-2 [N-(R)-(2(hydroxyaminocarbolyl) methyl)-4-methylpentanoyl-L-t-butyl-glycineL-alanine 2-aminoethyl amide] [a gift from Immmunex (Seattle, WA) or purchased from Biomol (Plymouth Meeting, PA)]. The astrocytes were incubated in the presence of these agents for different periods of time at $37^{\circ} \mathrm{C}$, washed with ice-cold PBS, and frozen in dry ice before protein extraction. To study the release of TGF $\alpha$, the astrocytes (300,000 astrocytes per well) were preincubated in the presence or absence of TAPI-2 ( $50 \mu \mathrm{M}$ in $500 \mu \mathrm{l}$ of ADM). After $30 \mathrm{~min}$ of incubation at $37^{\circ} \mathrm{C}$, the cells were exposed for $4 \mathrm{~h}$ to AMPA plus tACPD (100 $\mu \mathrm{M}$ each) or vehicle (DMEM medium) alone, with or without TAPI-2. At the end of this incubation period, both the medium and the cells were collected for TGF $\alpha$ measurement. The medium was transferred to tubes kept on ice and containing (final concentration) $1 \mathrm{~mm}$ phenylmethylsulfonyl fluoride, leupeptin at $10 \mu \mathrm{g} / \mathrm{ml}$, and $3 \mathrm{~mm}$ aprotinin. Thereafter, the tubes were centrifuged to remove cell debris, and the supernatants were saved at $-85^{\circ} \mathrm{C}$ until assayed for TGF $\alpha$. The cells were rapidly frozen on dry ice, extracted with $25 \mathrm{~mm}$ Tris buffer, $\mathrm{pH}$ 7.4, containing 1\% Triton X-100, and the same protease inhibitors mentioned above. The cell extracts were then frozen at $-85^{\circ} \mathrm{C}$ until assayed.

Determination of intracellular calcium levels. Astrocytes were seeded at 50,000 cells per well in black 96-well plates (Corning, Acton, MA) and grown for $48 \mathrm{~h}$ in serum-free ADM (Ma et al., 1999). At the end of this period, they were washed once in HBSS containing $130 \mathrm{~mm} \mathrm{NaCl}, 5 \mathrm{~mm}$ $\mathrm{KCl}, 1.5 \mathrm{~mm} \mathrm{CaCl}_{2}, 1 \mathrm{~mm} \mathrm{MgCl}_{2}, 5.5 \mathrm{~mm}$ glucose, 25 mм HEPES, pH 7.4, and $0.1 \% \mathrm{BSA}$ and loaded with $2 \mu \mathrm{M}$ fura- $2 \mathrm{AM}$ in HBSS (Invitrogen, Carlsbad, CA) for $60 \mathrm{~min}$ at room temperature. After three washes of 10 min each with HBSS, cellular fluorescence was determined using a fluorescence plate reader Flexstation II (Molecular Devices, Sunnyvale, CA) at an excitation of $335 \mathrm{~nm}$ and emission of $505 \mathrm{~nm}$. Measurements were made every $1.5 \mathrm{~s}$ for a total of $80 \mathrm{~s}$. After $20 \mathrm{~s}$ of basal fluorescence determination, $20 \mu \mathrm{l}$ of AMPA (500 $\mu \mathrm{M}$ in HBSS), tACPD (500 $\mu \mathrm{M})$, or both were automatically delivered to the wells. The results are expressed as $F / F_{o}$, i.e., the ratio of the fluorescence detected at any given time point divided by the initial fluorescence in that well; values are expressed as mean \pm SEM of eight wells per group.

Western blots. Cell cultures or tissues were lysed in Tris-buffered saline (TBS) lysis buffer containing 1\% (v/v) Nonidet P-40 and the protease inhibitors 1,10-phenantroline (10 mM; Sigma) and Iomastat ( $1 \mu \mathrm{M}$; Chemicon, Temecula, CA) to block TACE autodigestion (Schlöndorff et al., 2000). The lysates were centrifuged at $12,000 \times g$ for $10 \mathrm{~min}$, and 500 $\mu \mathrm{g}$ of the supernatant proteins were incubated with $20 \mu \mathrm{l}$ of concanavalin A-Sepharose beads (Sigma) for $2 \mathrm{~h}$ at $4^{\circ} \mathrm{C}$. The beads were washed three times with lysis buffer and boiled for 5 min in nonreducing sample buffer, sized fractionated by SDS-PAGE using a $8-16 \%$ gel, and transferred to polyvinylidene difluoride membranes (Millipore, Bedford, MA). Western blots were performed as described previously (Schlöndorff et al., 2000). Rabbit polyclonal antibodies against the cytoplasmic tail of TACE (kindly provided by Dr. Carl P. Blobel, Hospital for Special Surgery at Weill Medical College of Cornell University, New York, NY) were used at a 1:1000 dilution (overnight at $4^{\circ} \mathrm{C}$ ), followed by an antirabbit HRP antibody (1 h; 1:50,000 dilution). The signal was developed by enhanced chemiluminescence using the Western lightning chemiluminescence substrate (PerkinElmer Life Sciences, Boston, MA).

Reverse transcription-PCR. A DNA fragment derived from the coding region of rat TACE mRNA (GenBank accession number NM_020306) was generated by reverse transcription (RT)-PCR of total RNA extracted from prepubertal rat hypothalami, cultured astrocytes, and cultured tanycytes. Then, $500 \mathrm{ng}$ of total RNA were transcribed into cDNA in a volume of $20 \mu \mathrm{l}$ using $4 \mathrm{U}$ Omniscript reverse transcriptase (Qiagen, Valencia, CA), $20 \mathrm{U}$ of RNase inhibitor (Promega, Madison, WI), and 25 pmol of an oligo-dT primer. After $1 \mathrm{~h}$ of incubation at $37^{\circ} \mathrm{C}$, the reaction was terminated by heating at $95^{\circ} \mathrm{C}$ for $5 \mathrm{~min}$. PCRs were performed by using $2 \mu \mathrm{l}$ of each reverse transcription reaction and TaqDNA polymerase (Promega) in a volume of $25 \mu \mathrm{l}$. The thermocycling conditions were $95^{\circ} \mathrm{C}$ for $4 \mathrm{~min}$, followed by 35 cycles of $94^{\circ} \mathrm{C}$ for $15 \mathrm{~s}, 65^{\circ} \mathrm{C}$ for $30 \mathrm{~s}$, and $72^{\circ} \mathrm{C}$ for $30 \mathrm{~s}$, followed by a final extension period of $7 \mathrm{~min}$ at $72^{\circ} \mathrm{C}$. A 415 bp DNA fragment was amplified with the oligodeoxynucleotide primers (sense, 5' -CGTTGGGTCTGTTCTGGTTTTCTC-3'; and antisense, 5' GGCGGCCTTCTCACTCCTG-3') complementary to nucleotides 2016-2040 and 2412-2431, respectively, in the coding region of rat TACE mRNA. All cDNAs generated by RT-PCR were cloned into the riboprobe vector pGEM-T (Promega), and their identities were verified by sequencing.

Real-Time PCR. Primers were selected to amplify a 90 bp segment from rat TACE mRNA. The $5^{\prime}$ forward primer corresponds to nucleotides 1945-1965 (5'-ATTGAGCGGTTTTGGGATTTC- $\left.3^{\prime}\right)$, and the $3^{\prime}$ reverse primer is complementary to nucleotides 2015-2035 (5'AAACCAGAACAGACCCAACGA-3') in the TACE mRNA sequence. The internal fluorescent 29-nt-long oligodeoxynucleotide probe $\left(5^{\prime}\right.$ - 
CCAGCTGAgCATCAACACTTTTGGGaAGT-3'; PerkinElmer Applied Biosystems, Foster City, CA), complementary to nucleotides 19711999, was covalently linked to the fluorescent dye FAM at the $5^{\prime}$ end and the quencher dye TAMRA at the $3^{\prime}$ end. To normalize the mRNA values obtained, 18S ribosomal RNA was simultaneously measured in each sample using a set of primers purchased as a kit (TaqMan Ribosomal RNA Control Reagents kit; PerkinElmer Applied Biosystems). Other details of the real-time PCR procedure in our hands have been described previously (Romero et al., 2002; Shahab et al., 2005).

Determination of TACE-like activity. Tissues or cells were homogenized in $25 \mathrm{~mm}$ Tris buffer, $\mathrm{pH}$ 7.4, containing 1\% Triton X-100, $1 \mathrm{~mm}$ phenylmethylsulfonyl fluoride, leupeptin at $10 \mu \mathrm{g} / \mathrm{ml}$, and $3 \mathrm{~mm}$ aprotinin. The homogenates were centrifuged at 12,000 rpm for $20 \mathrm{~min}$, and the supernatants were stored at $-85^{\circ} \mathrm{C}$ after determining their protein concentration using the Bradford reagent (Bio-Rad, Hercules, CA). TACE activity was determined in a final volume of $100 \mu \mathrm{l}$, using $20 \mu \mathrm{g}$ of protein extract per well. The reaction was initiated with the addition of 10 $\mu$ м Mca-P-L-A-Q-A-V-Dpa-R-S-S-S-R-NH2 Fluorogenic Peptide Substrate III (R \& D Systems, Minneapolis, MN) and performed at $37^{\circ} \mathrm{C}$. TACE cleaves this peptide sequence between Ala and Val, separating the fluorochrome from the quencher, thus allowing the detection of the fluorescence (Jin et al., 2002). Fluorescence intensity was determined with the fluorescence plate reader Flex Station (Molecular Devices) using an excitation wavelength at $320 \mathrm{~nm}$ and emission at $405 \mathrm{~nm}$ every $10 \mathrm{~min}$ for $4 \mathrm{~h}$.

TGF $\alpha$ ELISA. A TGF $\alpha$ sandwich ELISA was developed using a "capture" and a biotinylated goat hTGF $\alpha$ antibody that recognize the mature form of human TGF $\alpha$ (R \& D Systems). Briefly, a 96-well plate (Corning, Corning, NY) was coated overnight at $4^{\circ} \mathrm{C}$ with the capture antibody at a concentration of $0.4 \mu \mathrm{g} / \mathrm{ml}$, diluted in carbonate coating buffer, $\mathrm{pH}$ 9.7. The next day, and after a single wash with PBS, the nonspecific sites were blocked with $300 \mu \mathrm{l}$ of PBS containing 1\% BSA and 5\% sucrose per well for $1 \mathrm{~h}$ at room temperature, followed by three washes with wash buffer (PBS and $0.05 \%$ Tween 20). Serial dilutions of a TGF $\alpha$ standard (Peprotech, Rocky Hill, NJ) were made using a range of concentrations varying from $10 \mathrm{ng} / \mathrm{ml}$ to $10 \mathrm{pg} / \mathrm{ml}$ in ADM. Duplicates of each standard or unknown were then pipetted into the wells at $100 \mu \mathrm{l} /$ well, and the reaction was allowed to proceed for $24 \mathrm{~h}$ at $4^{\circ} \mathrm{C}$. After three washes with wash buffer, biotinylated anti-hTGF $\alpha(300 \mathrm{ng} / \mathrm{ml})$ diluted in PBS and 1\% BSA was added to each well ( $100 \mu \mathrm{l} /$ well $)$ and allowed to react for $2 \mathrm{~h}$ at room temperature. After three washes, each well received $100 \mu \mathrm{l}$ of streptavidin-horseradish peroxidase (Amersham Biosciences, Buckinghamshire, UK) diluted 1:500 in Tris-buffered saline and 0.2\% Triton X-100, and the mixture was incubated for $30 \mathrm{~min}$ at room temperature. At the end of this period, the wells were washed again three times before developing the reaction with $100 \mu$ l of Ultra-TMB-ELISA (Pierce, Rockford, IL) for $30 \mathrm{~min}$ at room temperature. The reaction was then terminated by adding $50 \mu \mathrm{l}$ of $2 \mathrm{M} \mathrm{HCl}$. The absorbance was determined on a microplate reader (Bio-Tek Instruments, Winooski, VT) at $450 \mathrm{~nm}$.

Hybridization histochemistry. To localize TACE mRNA in the rat hypothalamus, we used a $415 \mathrm{nt}$ cRNA probe transcribed from the PCRgenerated cDNA template described above. The procedure used for tissue preparation and hybridization has been reported previously (Ma et al., 1992; Berg-von der Emde et al., 1995). In brief, the brains were fixed by transcardiac perfusion of $4 \%$ paraformaldehyde-borate buffer, $\mathrm{pH}$ 9.5. Both solutions were made with DEPC-treated water $(0.1 \%$ diethylpyrocarbonate) to minimize RNase contamination. After dissection of the brain, tissue blocks were postfixed overnight in the same fixative containing $20 \%$ sucrose, blocked and frozen on dry ice, and stored at $-85^{\circ} \mathrm{C}$ until sectioning, as reported previously (Ma et al., 1992; Berg-von der Emde et al., 1995). The sections $(30 \mu \mathrm{m})$ were cut on a sliding microtome, mounted on Superfrost Plus slides (Fisher Scientific, Santa Clara, CA), dehydrated under vacuum overnight, and then frozen at $-85^{\circ} \mathrm{C}$ until processing for hybridization. The hybridization procedure was that recommended by Simmons et al. (1989), as described previously by us (Ma et al., 1994b; Berg-von der Emde et al., 1995), using a $\left[{ }^{35} \mathrm{~S}\right] \mathrm{UTP}$-labeled cRNA probe. After an overnight hybridization at $55^{\circ} \mathrm{C}$, the slides were washed and processed for cRNA detection. After dehydration, the slides were dipped in NTB-2 emulsion and were ex- posed to the emulsion for 3 weeks at $4^{\circ} \mathrm{C}$. At this time, the slides were developed, stained with $0.1 \%$ thionin, quickly dehydrated in ascending alcohol concentrations, dried, and coverslipped for microscopic examination. Control sections were hybridized to a sense RNA probe transcribed from the same TACE cDNA template but linearized at the $3^{\prime}$ end to transcribe the sense strand of the template.

Immunohistochemistry confocal microscopy. To detect TACEimmunoreactive protein in cultured astrocytes and brain sections, we used a procedure described previously (Jung et al., 1997; Dziedzic et al., 2003) and rabbit polyclonal antibodies to the intracellular domain of rat TACE (Schlöndorff et al., 2000) generously provided by Dr. Carl P. Blobel or obtained from a commercial source (C-15, sc-6416; Santa Cruz Biotechnology, Santa Cruz, CA). In the case of astrocytes, the cultures were washed twice with PBS, pH 7.4, and fixed in 4\% paraformaldehyde for $30 \mathrm{~min}$ at room temperature. After extensive washes in $0.02 \mathrm{M}$ potassium phosphate buffer containing $0.9 \% \mathrm{NaCl}$ (KPBS), the cells were incubated for $15 \mathrm{~min}$ in KPBS-A (0.02 M KPBS containing $0.5 \%$ Triton $\mathrm{X}-100$ ), followed by $15 \mathrm{~min}$ in avidin blocking solution (avidin/biotin blocking kit; Vector Laboratories, Burlingame, CA) and $15 \mathrm{~min}$ in biotin blocking solution. After three washes in LKPBS (KPBS containing 2\% normal donkey serum and $0.5 \%$ Triton X-100), the cultures were incubated for $24 \mathrm{~h}$ at $4^{\circ} \mathrm{C}$ with the TACE antibodies (diluted 1:3000) in LKPBS. The immunoreaction was developed using the biotinylated tyramine enhancement method as described previously (Jung et al., 1997), with a biotinylated donkey anti-rabbit IgG (Jackson ImmunoResearch Laboratories, West Grove, PA) at 1:5000 dilution and an Alexa 488streptavidin fluorophore (Invitrogen) at 1:1000. Other cultures were incubated overnight at $4^{\circ} \mathrm{C}$ with a monoclonal antibody to GFAP (1:5000; Sigma), followed by $1 \mathrm{~h}$ incubation with fluorescein-conjugated horse anti-mouse Ig (1:250; Jackson ImmunoResearch) to develop the immunoreaction. We performed separate reactions for TACE and GFAP because, in initial cultures that were double stained for GFAP and TACE, we noticed that TACE was present in GFAP-negative astrocytic processes. Because GFAP has been reported to be absent in fine astrocytic processes (Derouiche and Frotscher, 2001; Chao et al., 2002), we visualized these processes by exposing the cultures to phallotoxin conjugated to Texas Red (1:150; Invitrogen) to label F-actin filaments. The cells were incubated with phallotoxin for $45 \mathrm{~min}$ at room temperature after completion of the TACE or GFAP immunoreactions.

For detection of TACE in brain sections, the brains were fixed by transcardiac perfusion of $4 \%$ paraformaldehyde-PBS, immersed in $20 \%$ sucrose-PBS for $24-48 \mathrm{~h}$, blocked, frozen on dry ice, and stored at $-85^{\circ} \mathrm{C}$ until sectioned at $30 \mu \mathrm{m}$ using a frozen sliding microtome. Floating sections were incubated overnight with the TACE antibodies at a 1:2000 dilution, and the reactions were developed as outlined above. To identify astrocytes, we stained the sections (overnight at $4^{\circ} \mathrm{C}$ ) with monoclonal antibodies to GFAP (1:5000; Sigma) and developed the reaction the next day with Texas Red goat anti-mouse IgG (1:250; Jackson ImmunoResearch). Tanycytes were identified using monoclonal antibodies against vimentin (1:600; Neomarkers, Union City, CA), a cytoskeletal protein used as a marker for these cells (Chauvet et al., 1998; De Seranno et al., 2004). When immunostaining for TGF $\alpha$ and TACE, the growth factor was identified using rabbit polyclonal antibodies (1:200; Peprotech), and the reaction was developed to a green color using biotinylated donkey anti-rabbit Ig (1:250; Jackson ImmunoResearch), followed by fluorescein-conjugated streptavidin (1:250; Jackson ImmunoResearch). TACE was identified with goat polyclonal antibodies directed against the C-terminus of the protein (sc-6316, 1:200; Santa Cruz Biotechnology), and the immunoreaction was developed to a red color using Alexa 568 donkey anti-goat Ig (1:250; Invitrogen). Cell nuclei were stained with Hoescht 33258 (Invitrogen) at $0.1 \mu \mathrm{g} / \mathrm{ml} \mathrm{KPBS}$ for 1 min after completion of the immunoreactions. Controls consisted of sections incubated without TACE antibodies but in the presence of either vimentin or GFAP antibodies or sections incubated without TGF $\alpha$ or TACE antibodies. Fluorescent images were acquired with either a Leica (Nussloch, Germany) TCS SP confocal microscope as described previously (Ma et al., 1999; DeFazio et al., 2002) or a Mariannas imaging workstation (Intelligent Imaging Innovations, Denver, CO). Slidebook 4.1 was used to con- 
struct a montage of large fields of view and for nearest neighbors or constraint iterative deconvolution and three-dimensional rendering.

Incubation of ME explants and measurement of LHRH release. During microdissection, the MEs were placed in small plastic vials precoated with $0.1 \%$ gelatin (one ME per vial). Thereafter, they were preincubated for 30 min in Krebs'-Ringer's bicarbonate buffer, $\mathrm{pH}$ 7.4, containing 4.5 $\mathrm{mg} / \mathrm{ml}$ D-dextrose at $37^{\circ} \mathrm{C}$ under an atmosphere of $95 \% \mathrm{O}_{2}, 5 \% \mathrm{CO}_{2}$ with shaking (60 cycles per minute), as described previously (Ojeda et al., 1986b, 1990). At the end of this period, the medium was discarded and replaced with fresh medium containing either TAPI-2 $(50 \mu \mathrm{M})$ or its diluent (PBS). After $1 \mathrm{~h}$ of incubation, the medium was replaced again, this time with medium containing AMPA and tACPD (500 $\mu \mathrm{M}$ each) in the presence or absence of TAPI-2, and the incubation was continued for another hour before collecting the medium for LHRH measurement. LHRH released to the incubation medium was detected by radioimmunoassay, as described previously (Ojeda et al., 1986a,b), using ${ }^{125} \mathrm{I}-$ labeled LHRH and the rabbit polyclonal antibody HU60, which recognizes the fully processed, mature decapeptide (Urbanski and Ojeda, 1990), at a 1:25,000 dilution.

Intrahypothalamic implants. To specifically block endogenous TACE activity in the ME, TAPI-2 was delivered to this region of the hypothalamus via a stereotaxically implanted cannula. TAPI-2 (5 mM in DMSO) was mixed with cocoa butter in a $1: 2(\mathrm{w} / \mathrm{w})$ ratio and tapped into the open end of a stainless steel 23-gauge cannula, as described previously (Ojeda and Ramirez, 1969; Ma et al., 1992). Control cannulas contained only $\mathrm{DMSO} / \mathrm{cocoa}$ butter. The cannulas were stereotaxically implanted into the ME or mammillary bodies of late juvenile (LJ) 28- to 29-d-old rats according to the following coordinates: $\mathrm{ME},-0.0 \mathrm{~mm}$ caudal to bregma, $0.0 \mathrm{~mm}$ lateral from midline, and $8.5 \mathrm{~mm}$ vertical from the surface of the brain; mammillary bodies, $-0.7 \mathrm{~mm}$ caudal to bregma, $0.0 \mathrm{~mm}$ lateral from the midline, and $8.5 \mathrm{~mm}$ vertical. After implantation, the cannulas were fixed with dental cement to the skull, and the skin wound was sutured with surgical clips.

Phases of sexual development. Changes in hypothalamic TACE gene expression and enzyme activity were determined at the different stages of puberty described previously (Ojeda and Urbanski, 1994; Ojeda and Skinner, 2005). If the vagina was not patent and the uterus weight was 60 $\mathrm{mg}$ or less, the animal was considered to be in the LJ phase of puberty [a stage previously termed anestrus (Ojeda and Urbanski, 1994)]. When the uterus was enlarged and had detectable fluid (an index of estradiol secretion), the animals were classified as being in the early proestrus phase. Animals showing a uterine weight of $200 \mathrm{mg}$ or more and a uterus "ballooned" with fluid were considered as late proestrus, i.e., the day of the first preovulatory surge of LHRH and gonadotropins. The next day is the day of first estrus. Ovulation takes place in the early morning hours of this day. The vagina is open, vaginal cytology shows a predominance of cornified cells, and the ovaries contain fresh corpora lutea. The first diestrus follows; at this time, leukocytes are the predominant cell type found in vaginal lavages.

Statistical analysis. The differences between several groups were analyzed by one-way ANOVA, followed by the Student-Newman-Keuls multiple comparison test for unequal replications.

\section{Results}

TACE is expressed in hypothalamic astrocytes and tanycytes TACE mRNA, detected by RT-PCR, was distinctly expressed in the hypothalamus of prepubertal female rats as a whole and in both astrocytes and tanycytes isolated from this region and cultured in serum-containing medium (Fig. 1A). In situ hybridization of brain sections from 30 - to 32-d-old late juvenile female rats demonstrated that, although TACE mRNA is expressed throughout the hypothalamus, it is also present in ependymal cells lining the wall of the third ventricle (Fig. $1 B$, arrowheads). A prominent site of expression is the ME, in which TACE mRNA appears to be most abundant in subependymal cells of the intermediate portion of the ME (Fig. $1 B$, arrows, $C$ ). This region contains astrocytes (Ma et al., 1999) and the intermediate cell
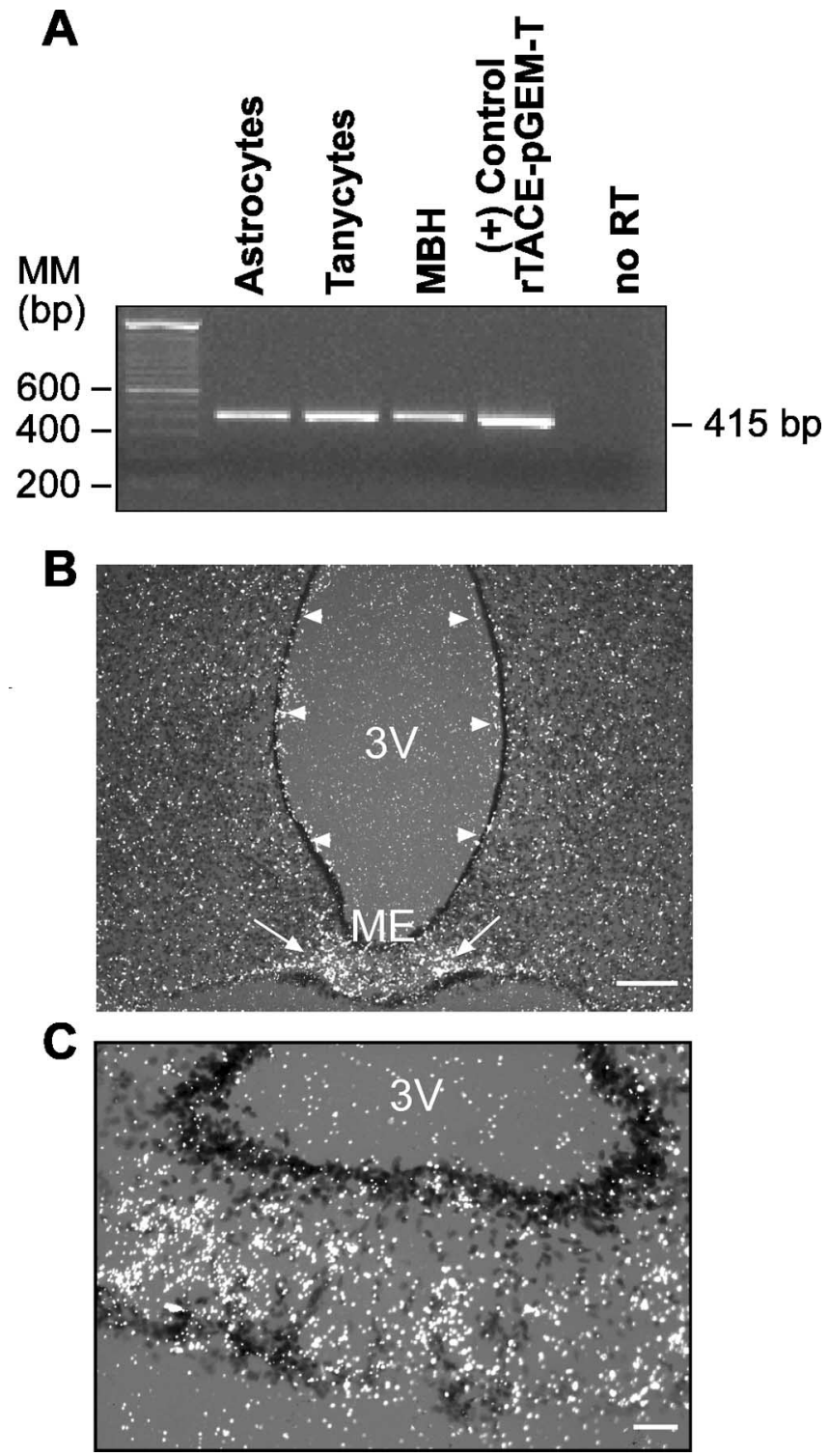

Figure 1. The TACE gene is expressed in both isolated hypothalamic glial cells and the intact rat hypothalamus. A, Detection by RT-PCR of TACE mRNA in cultures of purified astrocytes and ependymoglial cells (tanycytes) and in the MBH of immature female rats. MM, Molecular marker. $\boldsymbol{B}$, Cellular localization of TACE mRNA in the hypothalamus of prepubertal (30-d-old) female rats as detected by in situ hybridization using a $\left[{ }^{35} \mathrm{~S}\right]$ UTP-labeled CRNA probe. Although TACE mRNA-containing cells are present throughout the hypothalamus, including ependymal cells lining the wall of the third ventricle ( $3 \mathrm{~V}$; arrowheads), the most intense hybridization signal is observed in the ME (arrows). Scale bar, $200 \mu \mathrm{m}$. C, Higher-magnification image illustrating the abundance of TACE mRNA in glial cells of the ME. Scale bar, $50 \mu \mathrm{m}$.

type known as astrocytic tanycytes (Záborszky and Schiebler, 1978; Rützel and Schiebler, 1980).

Western blot analysis of proteins extracted from either hypothalamic astrocytes or the ME of 30-d-old rats demonstrated the presence of a triplet of $\sim 110 \mathrm{kDa}$ under nonreducing conditions identical in size to a protein species detected in COS cells (Fig. $2 A$ ) and that was previously demonstrated to correspond to the full-length TACE form containing the protein prodomain (Schlöndorff et al., 2000). A band of $\sim 75-80 \mathrm{kDa}$ detected in the $\mathrm{ME}$, astrocytes, and COS-7 cells likely represents mature TACE lacking the prodomain (Schlöndorff et al., 2000). When the proteins are size fractionated under reducing conditions, the 100 $\mathrm{kDa}$ protein migrates as a $120 \mathrm{kDa}$ species and the $75-80 \mathrm{kDa}$ as 


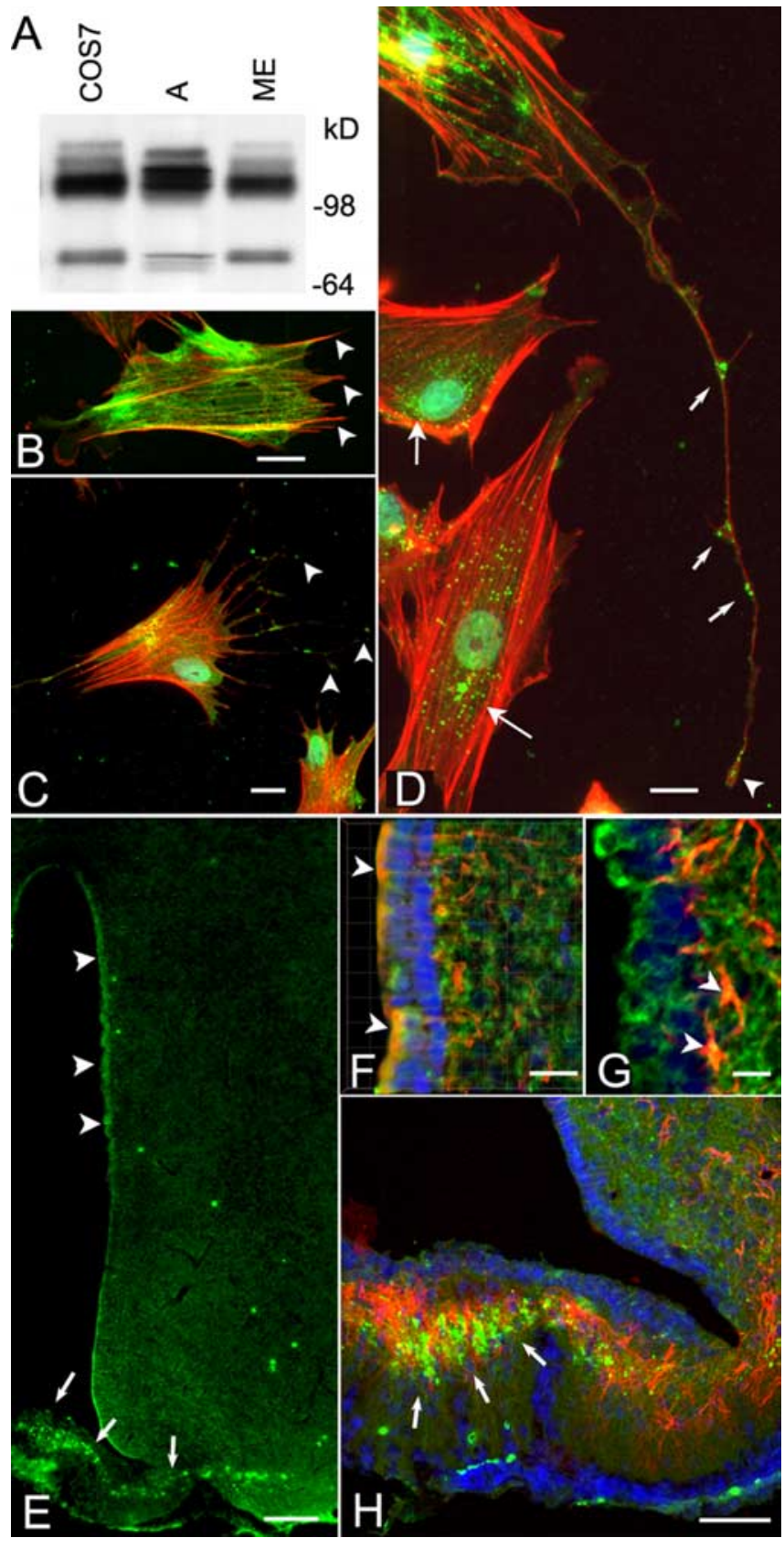

Figure 2. The TACE protein is present in hypothalamic glial cells and in the intact rat hypothalamus. $A$, Immunoblotting of Sepharose- concanavalin A-enriched cell lysates derived from hypothalamic astrocytes (A), the ME of the hypothalamus, and COS-7 cells (positive control) demonstrates the presence of a major immunoreactive species migrating at $\sim 110 \mathrm{kDa}$ under the nonreducing conditions used and that represent the full-length, unprocessed TACE. A smaller species of $\sim 75-80 \mathrm{kDa}$ corresponding to TACE lacking the prodomain (Schlöndorff et al., 2000) was also detected in the ME and COS cells and to a lesser extent in astrocytes. Protein samples were boiled in sample buffer in the absence of dithiothreitol and size fractionated on a $8-16 \%$ polyacrylamide gel before immunoblotting (see Material and Methods). $\boldsymbol{B}$, Detection of astrocytic processes not stained by GFAP antibodies, using phallotoxin conjugated to Texas Red. GFAP staining is shown as a green color; arrowheads point to some of the processes devoid of GFAP. C, D, Localization of TACE in cultured hypothalamic astrocytes. TACE was identified with rabbit polyclonal antibodies to its cytoplasmic tail domain, and the reaction was developed to a green color with Alexa 488 streptavidin. Thereafter, the cells were stained with phallotoxin conjugated to Texas Red to visualize actin in astrocytic processes that are devoid of GFAP staining. Notice that TACE immunoreactivity is present at the tip of astrocytic processes ( $\boldsymbol{C}$, arrowheads), in addition to having a perinuclear localization ( $\boldsymbol{D}$, long arrows). TACE is also detected along fine processes in which it appears to be most abundant at the tip of the processes $(\boldsymbol{D}$, arrowhead) and at bifurcation points ( $\boldsymbol{D}$, short arrows). $\boldsymbol{E}-\boldsymbol{H}$, Detection of TACE immunoreactivity in the hypothalamus of immature 30- to 32-d-old rats. Astrocytes were identified as such a $100 \mathrm{kDa}$ form (data not shown), as described previously (Schlöndorff et al., 2000).

Initial examination of cultured hypothalamic astrocytes using immunofluorescence confocal microscopy showed the presence of TACE in GFAP-positive astrocytic cell bodies (data not shown). However, there was also TACE immunoreactivity not associated with GFAP, suggesting that TACE might be abundant in astrocytic processes devoid of GFAP (Derouiche and Frotscher, 2001; Chao et al., 2002). To test this possibility, we stained the astrocytes with phallotoxin, a mushroom protein that binds to actin filaments that can recognize most astrocytic processes lacking detectable GFAP (Chao et al., 2002). As shown in Figure $2 B$, astrocytic processes positive for actin are indeed GFAP negative (arrowheads). Conversely, immunoreactive TACE is present not only in astrocytic cell bodies in which it exhibits a perinuclear localization (Fig. $2 D$, long arrows) but also in fine astrocytic processes $(C, D)$. Interestingly, TACE appears to be more abundant on the leading edge of the processes $(C, D$, arrowheads) and at the branching points in which new processes originate ( $D$, short arrows). Hypothalamic sections stained with the same TACE antibodies (which recognize the intracellular domain of the protein) demonstrated that, as was the case of TACE mRNA, TACE immunoreactivity is present throughout the hypothalamus (Fig. $2 E$ ). Its abundance, however, appeared to be greater in ependymal cells lining the third ventricle (arrowheads) and particularly in the ME (arrows). Three-dimensional reconstructions of higher-magnification images demonstrate that TACE is indeed present in vimentin-positive tanycytes (Fig. $2 F$, arrowheads). In addition to tanycytes (Fig. $2 F$, arrowheads, $G$, green staining), TACE is also detected in subependymal GFAPpositive astrocytes (Fig. $2 G$, arrowheads) and other cells devoid of GFAP immunoreactivity, probably neurons. In the ME, the astroglial expression of TACE is remarkably strong, because most of the immunoreactivity is localized to the intermediate region of the ME in which astrocytes are more densely packed (Fig. $2 \mathrm{H}$, arrows). Consistent with the presence of TACE in GFAP-negative astrocytic processes, a distinct fraction of TACE-immunoreactive material in the ME did not appear to overlap with GFAP (Fig. $2 H)$.

Double immunofluorescence for TGF $\alpha$ and TACE, using a different TACE antiserum (Santa Cruz Biotechnology) also directed against the TACE intracellular domain verified the aforementioned localizations and demonstrated that both TGF $\alpha$ positive ependymoglial cells lining the wall of the third ventricle and subependymal cells expressing TGF $\alpha$ also contain TACE (Fig. $3 A, B$ ). Although the presence of TACE in ependymal cells was unambiguous (arrowheads), its abundance in TGF $\alpha$-positive subependymal cells (presumably astrocytes) was remarkable (Fig. $3 A, B$, arrows). In the ME (Fig. 3C), TACE immunoreactiv-

with monoclonal antibodies to GFAP. Notice that, in this case, the immunoreaction was developed to a red color using Texas Red goat anti-mouse lgG. E, TACE immunoreactivity (green) is present in cells scattered throughout the hypothalamus, but it is particularly evident in ependymoglial cells (tanycytes) lining the third ventricle (3V; arrowheads) and the ME (arrows). $\boldsymbol{F}$, Three-dimensional rendering of a stack of images of the periventricular region showing the presence of TACE in ependymoglial cells (arrowheads) identified as tanycytes by vimentin immunostaining (red). Notice that TACE is also present in ependymoglial processes. $\mathbf{G}$, In addition to ependymoglial cells (green), TACE is also present in subependymal astrocytes (arrowheads). $\boldsymbol{H}$, TACE (green) is abundant in astrocytes (red) of the ME (arrows), but a substantial fraction of the TACE-immunoreactive material appear not to overlap with the GFAP staining, indicating the presence of TACE in GFAP-negative astrocytic processes. Blue, Hoechst nuclear stain. Scale bars: $\boldsymbol{B}, \boldsymbol{D}, \boldsymbol{F}, 20 \mu \mathrm{m} ; \boldsymbol{C}, 10 \mu \mathrm{m} ; \boldsymbol{E}, 100 \mu \mathrm{m} ; \boldsymbol{G}, 15 \mu \mathrm{m} ; \boldsymbol{H}, 40 \mu \mathrm{m}$. 
ity was detected in TGF $\alpha$-positive tanycytes (arrowheads) but much more abundantly in subependymal cells (arrows), shown in Figure 2 to be astrocytes. In the absence of TACE and TGF $\alpha$ antibodies, no immunostaining was detected (Fig. 3D).

\section{Hypothalamic astrocytes display TACE-like activity}

Various concentrations of protein extracts from cultured hypothalamic astrocytes were incubated with a TACE-selective fluorescent substrate for $4 \mathrm{~h}$, and the accumulation of fluorescent product was determined every $10 \mathrm{~min}$ (Fig. 4A). As shown in Figure $4 B$, the astrocyte extracts cleaved the fluorometric substrate in a dose- and time-dependent manner. To determine the specificity of this TACE-like enzymatic activity, the cell lysates were incubated with the fluorometric substrate in the presence of different doses of TAPI-2, a selective TACE inhibitor (Ohta et al., 2001; Neumann et al., 2004; Juanes et al., 2005) (Fig. 4C). The inhibitor reduced basal TACE activity to $33 \%$ of control levels at the highest dose tested (50 $\mu \mathrm{M})$ (Fig. $4 D)$. The residual activity seen in the presence of TAPI-2 likely reflects the involvement
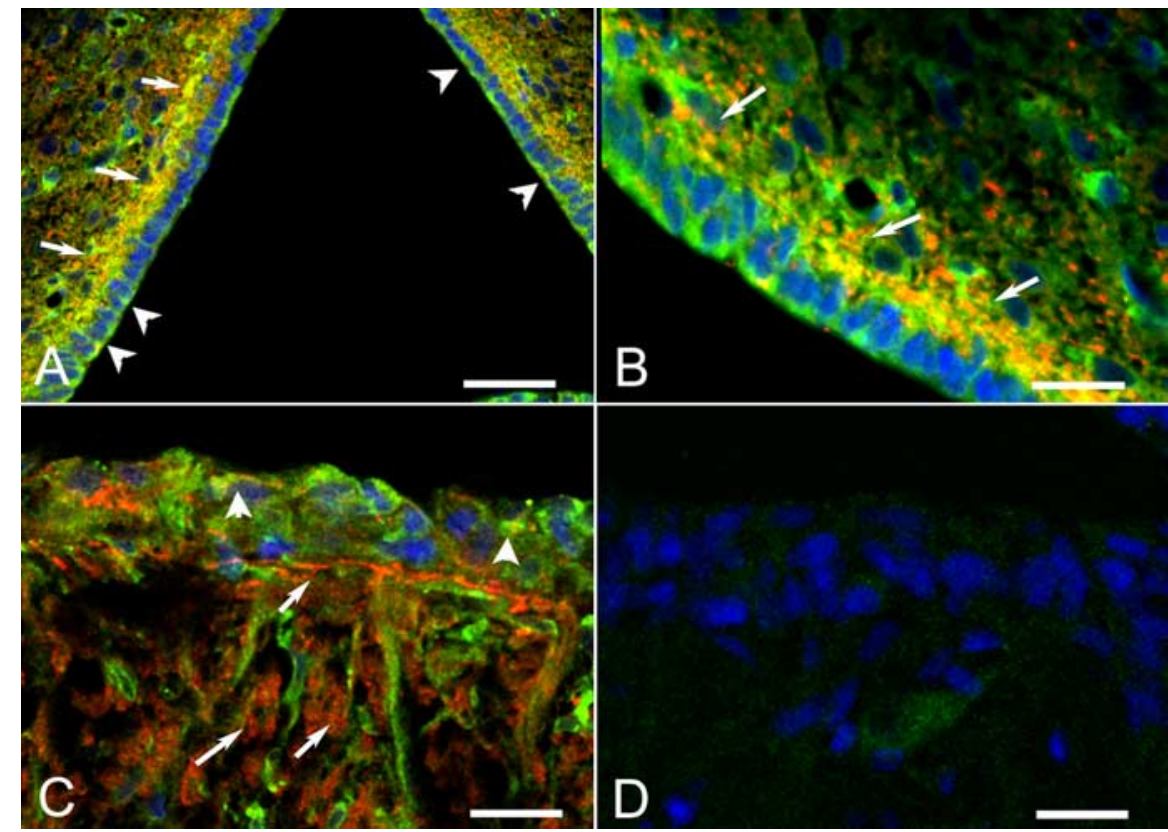

Figure 3. Colocalization of TGF $\alpha$ and TACE in ependymoglial and subependymal cells of the third ventricle (3V) and ME of immature female rats. TACE immunoreactivity was detected with goat polyclonal antibodies, and the reaction was developed to a red color with Alexa 568 donkey anti-goat Ig; TGF $\alpha$ was detected with rabbit polyclonal antibodies, and the reaction was developed to a green color with FITC-streptavidin. $\boldsymbol{A}$, TACE is present in both TGF $\alpha$-positive tanycytes (arrowheads) and in subependymal TGF $\alpha$-positive cells (arrows). $\boldsymbol{B}$, Higher-magnification view of $\boldsymbol{A}$ showing the abundance of TACE in TGF $\alpha$-positive subependymal cells (arrows). These cells are presumed to be astrocytes (see Fig. 2). $\boldsymbol{C}$, In the ME, TACE is predominantly localized to subependymal cells (arrows) and to a lesser extent to TGF $\alpha$-positive tanycytes (arrowheads). $\boldsymbol{D}$, No immunostaining is detected in the ME of a section processed in the absence of both TACE and TGF $\alpha$ antibodies. Scale bars: $\boldsymbol{A}, 40 \mu \mathrm{m} ; \boldsymbol{B}-\boldsymbol{D}, 20 \mu \mathrm{m}$. of TAPI-2-insensitive proteases because, at this concentration, TAPI-2 completely blocks TGF $\alpha$ ectodomain shedding (Arribas et al., 1996, 1997; Juanes et al., 2005). Accordingly, all subsequent experimental values are reported after subtraction of this basal, TACE-independent activity. Because TACE-like activity was linear during the first $60 \mathrm{~min}$ of the incubation period and the enzymatic activity was maximally blocked by TAPI- 2 at $50 \mu \mathrm{M}$, we chose this time and blocker concentration for all additional experiments.

\section{Activation of astrocytic AMPARs and mGluRs stimulates TACE-like activity in a $\mathrm{Ca}^{2+}$ and protein kinase C-dependent manner}

In a previous study, we showed that coactivation of mGluRs and AMPARs in hypothalamic astrocytes leads to a metalloproteinasedependent increase in erbB1 phosphorylation (Dziedzic et al., 2003). TACE is required for the release of mature TGF $\alpha$ from its membrane-anchored precursor (Borrell-Pagès et al., 2003; Hinkle et al., 2003), and this process is $\mathrm{Ca}^{2+}$ and protein kinase $\mathrm{C}$ (PKC) dependent (Pandiella and Massague, 1991a,b; Harano and Mizuno, 1994; Baselga et al., 1996). We therefore hypothesized that the increase in TACE elicited by coactivation of astrocytic mGluRs and AMPARs might require an elevation in intracellular $\mathrm{Ca}^{2+}$ levels (Innocenti et al., 2000).

To test this hypothesis, we first determined the effect of AMPA and tACPD on intracellular $\mathrm{Ca}^{2+}$ levels using astrocytes loaded with fura-2. Although each receptor agonist applied individually induced an increase in intracellular $\mathrm{Ca}^{2+}$, tACPD caused a faster increase (Fig. 5A). When used together, the agonists induced an even larger and more sustained change in intracellular $\mathrm{Ca}^{2+} \mathrm{lev}$ els than after their individual application. Astrocytic TACE activity, determined under similar conditions, was affected by neither AMPA nor tACPD applied individually (Fig. 5B). However, after concomitant application of the agonists, TACE activity increased rapidly (in $<5 \mathrm{~min}$ ), remaining elevated for the duration of the experiment (30 $\mathrm{min}$ ) (Fig. 5B). The increase was abolished in the presence of TAPI-2. These results are in harmony with a previous study showing that coactivation of AMPARs and mGluRs, but not the individual stimulation of each receptor, results in astrocytic prostaglandin $\mathrm{E}_{2}\left(\mathrm{PGE}_{2}\right)$ release (Bezzi et al., 1998). They are also consistent with our previous observations showing that only costimulation of both receptor subtypes causes cellular redistribution of erbB receptors and their ligands and transactivation of erbB receptors in astrocytes (Dziedzic et al., 2003).

To determine whether the changes in intracellular calcium levels and the increase in TACE activity induced by AMPA/ tACPD stimulation are functionally related, we studied the dependence of AMPA and tACPD-induced TACE activity on the availability of extracellular and intracellular $\mathrm{Ca}^{2+}$. Because it has been shown in other cellular systems that increases in TACE activity require activation of PKC (Montero et al., 2002), we also determined the consequences of blocking protein kinase $\mathrm{C}$ activity on the AMPARs and mGluRs-dependent increase in TACE activity. Hypothalamic astrocytes were stimulated with AMPA and tACPD for $15 \mathrm{~min}$ in the presence of the extracellular $\mathrm{Ca}^{2+}$ chelating agent EGTA, the membrane-permeable $\mathrm{Ca}^{2+}$ chelating agent BAPTA-AM, or the protein kinase $\mathrm{C}$ blocker $\mathrm{H} 7$. When the extracellular $\mathrm{Ca}^{2+}$ was sequestered with $1 \mu \mathrm{M}$ EGTA, AMPA/ tACPD- induced TACE activity was reduced by $50 \%$ (Fig. 5 C). A more pronounced reduction was observed in the presence of 1 $\mu \mathrm{M}$ BAPTA-AM, indicating that induction of TACE activity requires an increase in cytosolic free $\mathrm{Ca}^{2+}$ concentrations and that this increase is dependent on both an influx of extracellular $\mathrm{Ca}^{2+}$ and a redistribution of intracellular $\mathrm{Ca}^{2+}$ from microsomal stores. Blockade of protein kinase C activity with $10 \mu \mathrm{M} \mathrm{H} 7$ abol- 
A

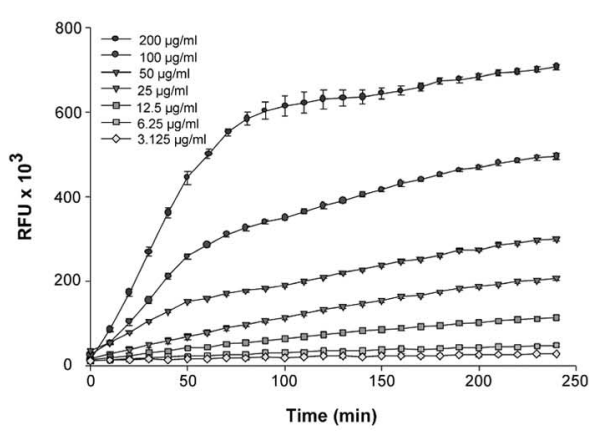

C

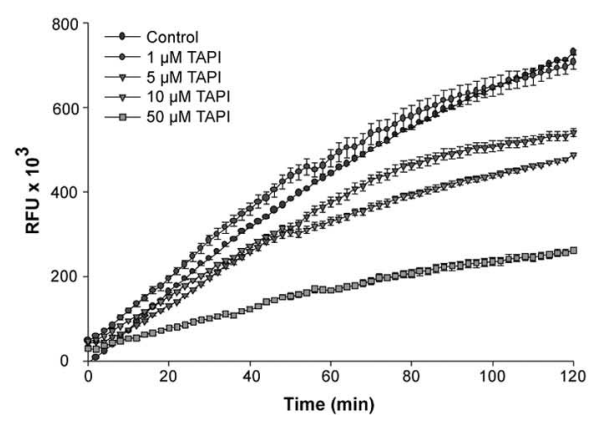

\section{B}

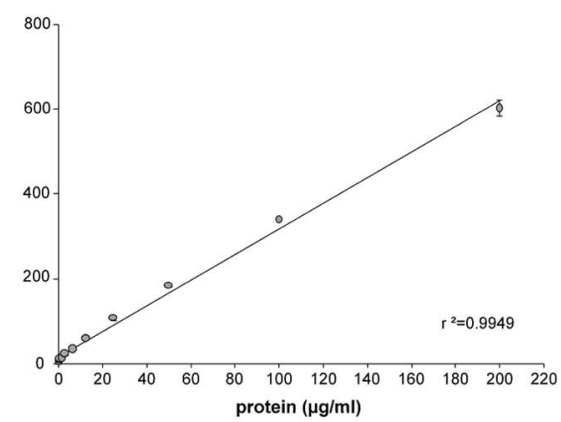

D

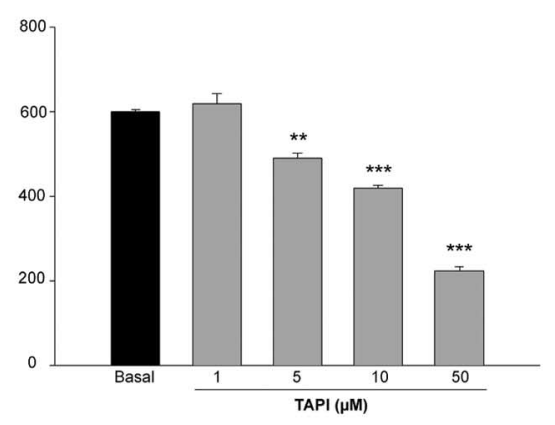

Figure 4. Assay of TACE-like activity using the TACE fluorescent substrate Fluorogenic Peptide Substrate III. $\boldsymbol{A}$, Serial dilutions of protein extracts from hypothalamic astrocytes incubated with a single concentration $(10 \mu \mathrm{g})$ of fluorescent substrate. The reactions were performed at $37^{\circ} \mathrm{C}$, and the fluorescence was determined at $10 \mathrm{~min}$ intervals. $\boldsymbol{B}$, Linear correlation between the intensity of the fluorescent reaction, determined after $2 \mathrm{~h}$ of incubation, and the amount of protein added to the reaction. $\boldsymbol{C}$, The specificity of the reaction was determined by incubating the protein extracts with increasing doses of TAPI-2 (a selective TACE inhibitor). The TACE activity measured after $2 \mathrm{~h}$ of incubation was dose dependently inhibited by TAPI-2, with a maximum of $65 \%$ inhibition at a $50 \mu \mathrm{m}$ dose $(\boldsymbol{D}) .{ }^{* *} p<0.01$ and ${ }^{* * *} p<0.001$ versus control group $(n=7-8$ independent observations per group). RFU, Relative fluorescence units.

ished the AMPA/tACPD-induced changes in TACE activity, indicating that protein kinase $\mathrm{C}$ is an essential component of the signaling cascade set in motion by the coactivation of AMPARs and mGluRs to stimulate TACE activity (Fig. 5C). Basal TACE activity remained unchanged in the presence of each of these blockers alone (data not shown).

\section{TACE is required for glutamate receptor-dependent} astrocytic TGF $\alpha$ release

It has been shown previously by several authors that TACE is required for the ectodomain shedding of TGF $\alpha$ in different cell types (Arribas et al., 1997; Peschon et al., 1998; Borrell-Pagès et al., 2003; Hinkle et al., 2003; Sahin et al., 2004). However, whether neurotransmitters can induce release of mature TGF $\alpha$ from either neurons or glial cells and whether they use TACE in the process is unknown. To determine whether the glutamate receptor-dependent transactivation of astrocytic erbB-mediated signaling we reported previously (Dziedzic et al., 2003) involves TACE-dependent activation of TGF $\alpha$ release, we treated hypothalamic astrocytes with AMPA/tACPD for several lengths of time. Because the sensitivity of the TGF $\alpha$ assay allows one to reliably measure the endogenous peptide only after its has accumulated in the culture medium, we first measured basal TGF $\alpha$ levels at several intervals after a mock stimulation in ADM and selected $4 \mathrm{~h}$ as the best poststimulation interval. As shown in Figure 6A, AMPA plus tACPD (at $100 \mu \mathrm{M}$ each) significantly increased TGF $\alpha$ release, and this increase was prevented by blocking TACE activity with TAPI-2. The increase in TGF $\alpha$ levels

in the culture medium was accompanied by a significant decrease in TGF $\alpha$ cell content, and again this decrease was prevented by blockage of TACE activity with TAPI-2 (Fig. 6B).

TACE activity increases in the median eminence at the time of first proestrus To determine whether TACE activity changes in the hypothalamus at the time of female puberty, we measured this activity at different stages of pubertal development. As seen in Figure 7, TACE activity selectively increased in the ME (Fig. 7A), at the developmental stage (late proestrus) when the first preovulatory surge of gonadotropins takes place. The increase was stage and region specific because the enzyme activity remained unchanged both before and after late proestrus (Fig. 7A), and was not seen in the rest of the hypothalamus (Fig. 7B). Because TACE activity is elevated at the time when circulating estradiol levels are maximally increased (Ojeda and Terasawa, 2002), we sought to determine whether estradiol at preovulatory levels could increase TACE activity in hypothalamic astrocytes in vitro. As seen in Figure $7 C$, estradiol induced TACE activity already at the concentration of $1 \mathrm{~nm}$, which is similar to the concentration of estradiol in plasma at the time of first proestrus (Andrews et al., 1981).

To determine whether changes in hypothalamic TACE gene expression may also occur in association with female sexual maturation, the content of TACE mRNA in the ME was determined by real-time PCR at different phases of puberty. No changes in TACE mRNA abundance were seen at any stage of the pubertal process (Fig. $7 D$ ). Thus, puberty-related changes in hypothalamic TACE activity appear to occur selectively in the ME, in the absence of changes in gene expression.

\section{Activation of AMPARs and mGluRs in isolated MEs causes a TACE-dependent increase in LHRH release}

Because TGF $\alpha$-dependent activation of erbB-1 receptors in the ME causes LHRH release (Ojeda et al., 1990; Prevot et al., 2003a), we sought to determine whether stimulation of the ME with AMPA and tACPD elicits LHRH release and whether this effect is affected by blocking TACE enzymatic activity. Microdissected ME explants exposed for $1 \mathrm{~h}$ to AMPA plus tACPD (500 $\mu \mathrm{M}$ each) responded with a significant increase in LHRH release, which was prevented by TAPI-2 (Fig. 8). Thus, concomitant stimulation of AMPARs and mGluRs in the ME leads to a TACE-dependent increase in LHRH release, suggesting that this increase requires activation of a glia-dependent pathway.

\section{In vivo blockade of TACE activity targeted to the ME delays female puberty}

In view of the aforementioned results, we next determined whether blockade of TACE activity targeted to the ME would delay the onset of female puberty. TAPI-2 administrated via a stereotaxically implanted cannula into the ME (Fig. $9 A, B$ ) mark- 

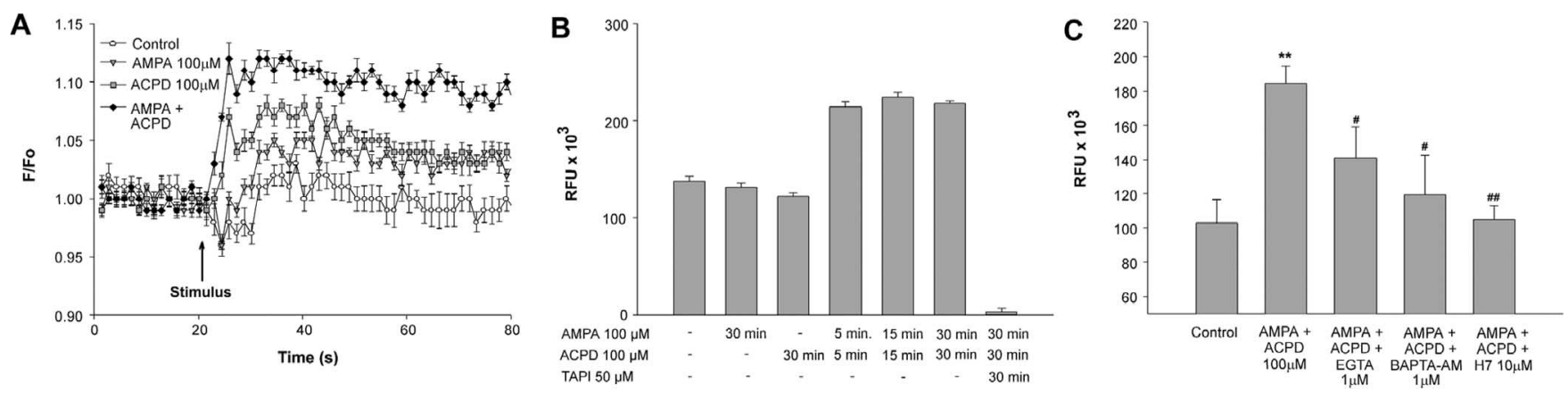

Figure 5. Concomitant activation of astrocytic AMPARs and $m G$ luRs results in a $\mathrm{Ca}^{2+}$ and protein kinase C-dependent increase in TACE-like activity. $A$, Coactivation of AMPARs and $m G$ luRs with AMPA plus tACPD (at $100 \mu \mathrm{m}$ each) results in a sustained increase in intracellular $\mathrm{Ca}^{2+}$ levels, determined in monolayers of hypothalamic astrocytes loaded with fura-2 AM. B, TACE-like activity is also increased when AMPA and ACPD are administrated together, and this increase is prevented by TAPI-2, a selective TACE inhibitor. C, The increase in astrocytic TACE-like activity induced by AMPA plus tACPD is inhibited by sequestering either extracellular or intracellular $\mathrm{Ca}^{2+}$ with the chelating agents EGTA and BAPTA-AM, respectively (each agent at $1 \mu \mathrm{m}$ ); glutamate receptor agonistinduced TACE-like activity is prevented by inhibiting protein kinase $C$ with H7. In $B, p<0.001$ untreated and AMPA or ACPD only versus AMPA plus ACPD and AMPA plus ACPD plus TAPI. In C, ** $p<$ 0.01 versus control group; $\#<0.05$ and ${ }^{\# \#} p<0.01$ versus AMPA plus ACPD group ( $n=6-8$ independent observations per group). RFU, Relative fluorescence units.

A
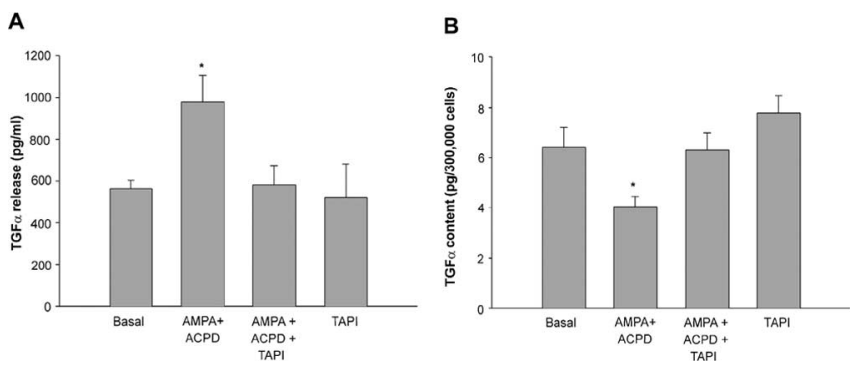

Figure 6. Simultaneous stimulation of AMPARs and mGluRs elicits a TACE-dependent increase in TGF $\alpha$ release from hypothalamic astrocytes. A, Accumulation of TGF $\alpha$ in the culture medium increases after exposing hypothalamic astrocytes to the glutamate receptor agonists AMPA plus TACPD (100 $\mu \mathrm{m}$ each), and this increase is prevented by blockade of TACE activity with TAPI-2. B, The cellular content of TGF $\alpha$ decreases in AMPA plus ACPD-treated astrocytes, concomitantly with the enhanced release of the mature peptide into the culture medium, and the decrease is prevented by blocking TACE activity with TAPI-2. All measurements were made after a $4 \mathrm{~h}$ incubation period with the receptor agonists. TGF $\alpha$ was measured with an ELISA that uses antibodies directed against the TGF $\alpha$ mature peptide and that is able to detect both the cleaved peptide and the peptide still attached to its precursor. ${ }^{*} p<0.05$ versus all other groups ( $n=8-12$ independent observations per group).

edly delayed the onset of puberty, as assessed by the age at first ovulation (Fig. 9C,D). By the time all control animals receiving the vehicle alone and all animals in which the TAPI-2 implants were placed in the mammillary bodies had ovulated, only one of six rats receiving TAPI-2 in the ME had reached puberty (Fig. 9 C). The mean age at first ovulation was similar in the two controls groups but significantly delayed in rats implanted with TAPI-2 into the ME (Fig. 9D). Thus, activation of TACE activity in the $\mathrm{ME}$ is required for the timely initiation of the pubertal process.

\section{Discussion}

The present results identify a proteolytic process in the cell-cell signaling mechanism used by glutamatergic neurons to communicate with hypothalamic astrocytes. By rapidly activating TACE, the protease responsible for the proteolytic shedding of proTGF $\alpha$ (Arribas et al., 1997; Peschon et al., 1998), stimulation of astrocytic glutamate receptors causes TGF $\alpha$ release, thereby setting in motion a TGF $\alpha /$ erbB1 receptor-dependent pathway that is crucial for astrocytic back-signaling to those neuroendocrine neurons that control sexual development (Ojeda and Terasawa, 2002). We further show that TACE activation requires the concomitant stimulation of AMPARs and mGluRs, an increase in intracellular $\mathrm{Ca}^{2+}$ levels, and protein kinase $\mathrm{C}$ activity. The physiological importance of this excitatory amino acid receptordependent increase in extracellular protease activity is evidenced by both its conspicuousness in the ME of the hypothalamus, a region enriched in glial cells, and by the delay in puberty resulting from the blockage of TACE activity targeted to this region of the brain.

Glutamatergic neurons communicate with associated astrocytic networks via ionotropic (AMPA/kainate) and mGlu receptors (Stella et al., 1994; Steinhäuser and Gallo, 1996; Bezzi et al., 1998; Dziedzic et al., 2003; Matthias et al., 2003). Coactivation of these two receptors subtypes on astrocytes, but not activation of each receptor alone, results in glutamate release, a process that requires both $\mathrm{Ca}^{2+}$ mobilization and formation of prostaglandins (Bezzi et al., 1998). Astrocytes of the neuroendocrine brain display AMPAR containing the subunits 2 and 3 and mGluR subtype 5 (Dziedzic et al., 2003). Coactivation of these receptors results in a cascade of events that include recruitment of erbB1 and erbB4 receptors and their ligands, TGF $\alpha$ and neuregulin- $\beta 1$ (NRG- $\beta 1$ ), to the cell membrane and transphosphorylation of both receptors (Dziedzic et al., 2003). A general inhibitor of metalloprotease activity prevented erbB receptor transphosphorylation, suggesting that regulation of ligand availability to erbB receptors might be a step required for these receptors to be activated in response to glutamatergic stimulation. The present results offer experimental evidence in support of this view and identify for the first time a role for metalloproteases in neuronglia communication.

It is rather recently that roles for metalloproteases and ADAMs in neuron-to-neuron communication have been identified (McFarlane, 2003). For instance, MMPs contribute to regulating axonal guidance (Galko and Tessier-Lavigne, 2000), ADAM 23 might play a role in regulating neuronal connectivity (Leighton et al., 2001), and MMP9 is involved in transmitterdependent dendritic remodeling of the mammalian hippocampus (Kaczmarek et al., 2002). To the best of our knowledge, no reports have appeared demonstrating an involvement of either MMPs or ADAMs in neuron-glia communication, although such a role was suggested by the presence of the Dm1-MMP in the Drosophila midline glia (Llano et al., 2000). Our results indicate that TACE is expressed in astroglial cells of the hypothalamus and ependymoglial cells of the third ventricle and ME. A more detailed examination of astrocytes in culture demonstrated that, in these cells, TACE is located both perinuclearly (presumably asso- 
A

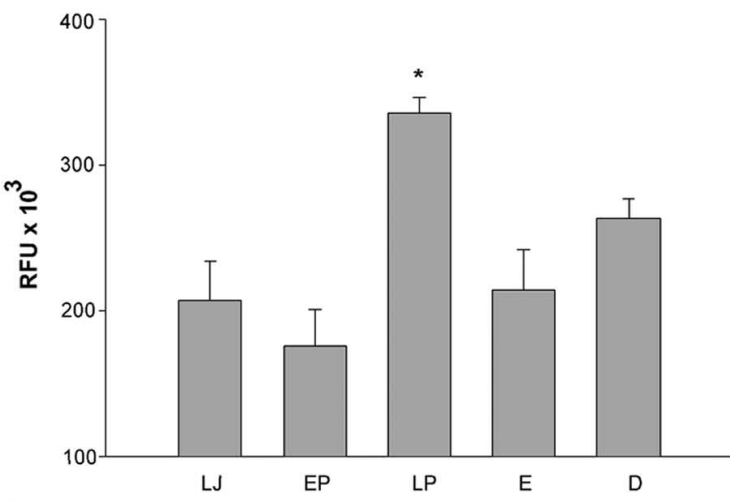

B

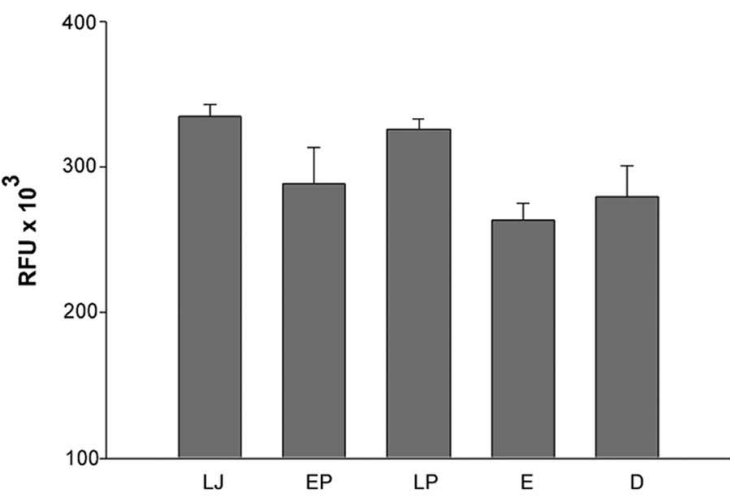

C
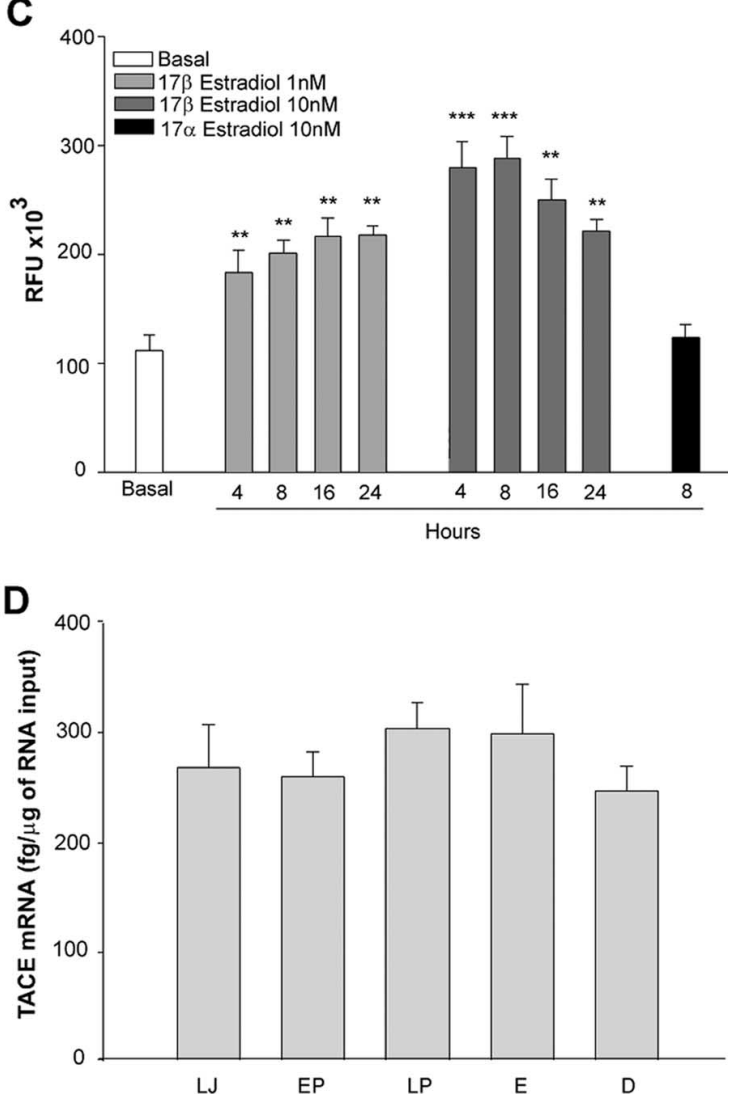

Figure 7. The onset of puberty in female rats is accompanied by ME-specific changes in TACE-like activity in the absence of changes in TACE mRNA expression. $\boldsymbol{A}$, TACE-like activity increases selectively in the ME of peripubertal female rats on the day of the first preovulatory $L H$

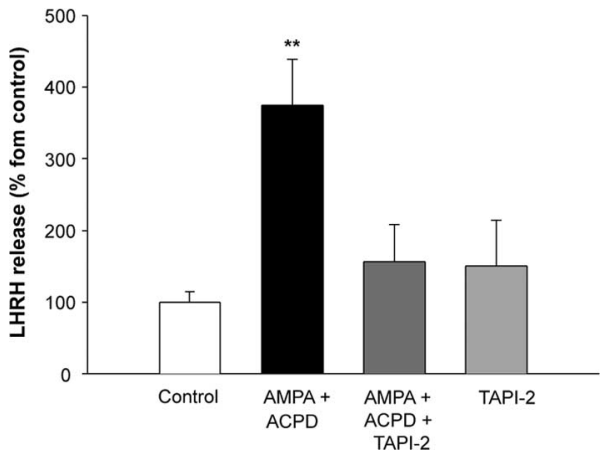

Figure 8. Concomitant stimulation of AMPARs and mGluRs with AMPA plus ACPD (500 $\mu \mathrm{M}$ each) elicits a TACE-dependent LHRH release from ME explants incubated in vitro with the agonists. The increase in LHRH release was prevented by blocking TACE activity with TAPI-2. ${ }^{* *} p<0.01$ versus all other groups ( $n=6$ independent observations per group).

ciated with the endoplasmic reticulum) and, surprisingly, at both the tip of astrocytic processes and in branching points in which new processes originate. Such TACE "hotspots" may have considerable physiological significance, because TACE might act within these microdomains to process the ectodomain of growth factor receptors and ligands involved in glia-to-neuron communication, such as the TGF $\alpha$-erbB1 signaling complex. The emerging role of MMPs in axonal guidance (McFarlane, 2003), and remodeling of both neuronal connections (Kaczmarek et al., 2002) and the extracellular matrix (Llano et al., 2000), raises additional possibilities.

In addition to TGF $\alpha$, TACE is required for the ectodomain release of other components of the ligand-erbB receptor complex involved in the glial control of LHRH secretion, including NRGs (Montero et al., 2000) and erbB-4 receptors (Rio et al., 2002). Thus, the effects of inhibiting TACE activity on LHRH secretion and the onset of puberty cannot be attributed exclusively to a defect in TGF $\alpha$-dependent activation of erbB1. Instead, it is most likely that these effects reflect the combined loss of TGF $\alpha$ and NRG signaling capabilities because, in the absence of ectodomain shedding, neither TGF $\alpha$ (Peschon et al., 1998; Borrell-Pagès et al., 2003) nor NRGs (Liu et al., 1998) are capable of activating their respective receptors. It is also unlikely that the inhibition of TACE-like enzymatic activity detected with the fluorescence substrate we used reflects an exclusive loss of TACE activity, because ADAM-10 activity (which is inhibited by TAPI-2) is also detected using this substrate (Neumann et al., 2004). The importance that ADAM-10 might have in neuroendocrine function is, however, unclear. Based on these considerations, it would appear reasonable to conclude that, among the erbB-dependent signaling complexes requiring ligand ectodomain shedding for activation, those mediated by TGF $\alpha$ and NRGs are the most relevant to the control of LHRH release and,

$\leftarrow$

surge. ${ }^{*} p<0.05$ versus all other groups ( $n=7-8$ rats per group). $\boldsymbol{B}$, This increase is not detected in the rest of the hypothalamus. C, Hypothalamic astrocytes respond to preovulatory levels of estradiol (similar to those seen on the day of first proestrus, $L P$ ) with increased TACE activity. ${ }^{* *} p<0.01,{ }^{* * *} p<0.001$ versus basal group; $n=6$ wells per group. $\boldsymbol{D}$, The increase in TACE-like activity in the ME is not accompanied by corresponding changes in mRNA expression. $L$, Late juvenile, prepubertal rats; EP, early proestrus, the phase of puberty when estradiol secretion begins to increase driven by an enhanced pulsatile LH release; LP, late proestrus, this stage corresponds to the first proestrus when the first preovulatory surge of gonadotropins takes place; $E$, the first estrus, both vaginal opening and the first ovulation takes place on this day; D, the day of the first diestrus, corresponding to the phase of puberty when the first functional corpora lutea are formed. RFU, Relative fluorescence units. 
hence, sexual development. Of these two systems, we selected TGF $\alpha$ as the prototype for this study not only because glial cells of the ME (including astrocytes and tanycytes) contain TGF $\alpha$ and its erbB1 receptor (Ma et al., 1992, 1994c) but also because the targeted manipulation of erbB1 receptor function in the ME affects the onset of female puberty ( $\mathrm{Ma}$ et al., 1992). Whereas blocking the receptors delays puberty (Ma et al., 1992), their activation advances sexual development (Rage et al., 1997).

The present results indicate that the ME may be a major site of glutamate/erbBdependent neuron-glia bidirectional communication. Relevant to this concept are the findings that astrocytic processes are rich in glutamate receptors (Matute et al., 1994; Eyigor and Jennes, 1998; Kawakami, 2000), that stimulation of neuronal fibers results in astrocytic calcium waves confined to specific glial microdomains (Grosche et al., 1999), and that glutamate released by astrocytes can enhance neuronal activity by acting on axonal receptors (Semyanov and Kullmann, 2001). In fact, the ME is not only rich in glial cells but also in axons from both neuroendocrine neurons that release their secretory products into the portal vasculature and non-neuroendocrine neurons controlling neurosecretion (Kobayashi et al., 1972; Page, 1994).

The need for simultaneous activation of AMPARs and mGluRs to enhance TACE activity and induce TGF $\alpha$ release is consistent with previous observations showing that such a coactivation is required to both induce astrocytic glutamate and $\mathrm{PGE}_{2}$ release (Bezzi et al., 1998) and transactivate glial erbB receptors (Dziedzic et al., 2003). Because hypothalamic astrocytes contain $\mathrm{Ca}^{2+}$-impermeable (GluR2), in addition to $\mathrm{Ca}^{2+}$-permeable (GluR3), AMPARs (Dziedzic et al., 2003), it is plausible that the underlying mechanism of this codependency involves the functional association of $\mathrm{Ca}^{2+}$-impermeable AMPARs with mGluRs to cause a longer-lasting $\mathrm{Ca}^{2+}$ mobilization, as shown recently in hippocampal interneurons (Topolnik et al., 2005). In fact, our results show that both the magnitude and duration of $\mathrm{Ca}^{2+}$ mobilization are greater when astrocytes are subjected to concomitant AMPA-mGluR stimulation than when each receptor is stimulated separately. Such an enhanced response might be necessary to ensure adequate activation of $\mathrm{PKC}$, the most important regulatory mechanism controlling protein ectodomain shedding in general (Kiessling and Gordon, 1998) and TACE activity in particular (Montero et al., 2002). In keeping with this concept, our results show that $\mathrm{PKC}$ is required for glutamate receptordependent TACE activation. Because $\mathrm{Ca}^{2+}$ enhances the activity of TGF $\alpha$ convertases other than TACE (C. Blobel, personal communication), it is possible that glial AMPARs/mGluRs might use another metalloprotease, in addition to TACE, to elicit TGF $\alpha$ release. Of note, our results show that glutamate-induced TGF $\alpha$ release from hypothalamic astrocytes, but not basal TGF $\alpha$ release, was blocked by TAPI-2, suggesting that, as previously shown in immortalized mouse monocytes (Doedens et al., 2003), basal TGF $\alpha$ shedding is a TACE-independent process. VMH, ventromedial nucleus.
B
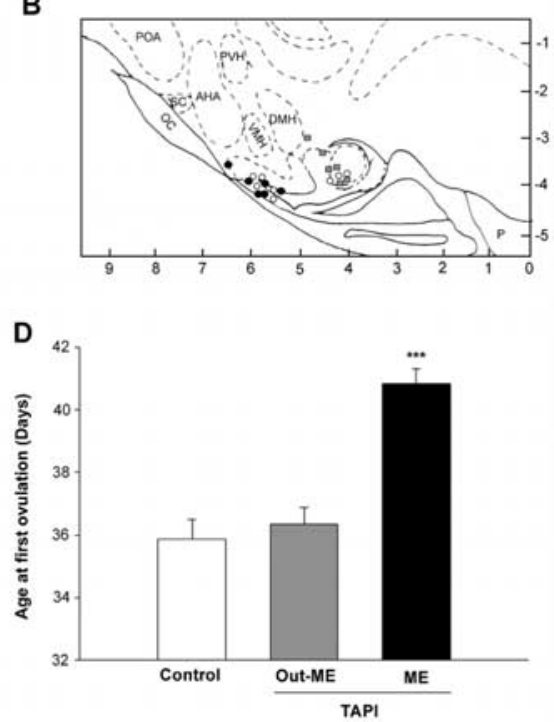

Figure 9. In vivo blockade of TACE activity targeted to the ME of the hypothalamus delays the onset of puberty in female rats, mean a

Our in vivo studies show that TACE-like activity, but not TACE mRNA abundance, increases selectively in the ME on the day of first proestrus. This suggests that, as observed in human cells in vitro (Black et al., 1997), the availability of TACE within the ME depends on inputs regulating its protease activity rather than on changes in gene expression. The pubertal increase in ME TACE activity may be caused, at least in part, by the elevated estrogen levels that characterize this phase of sexual development (Ojeda and Terasawa, 2002). As shown here, this effect is directly exerted on astrocytes, but it may also result from an action of estrogen on glutamatergic neurons signaling to astrocytes. By showing that glial cells of the ME are rich in TACE and that the in vivo pharmacological blockade of TACE activity targeted to the ME delays the first ovulation, our results suggest that activation of metalloprotease activity in this region of the neuroendocrine brain is a required step in the process by which glial cells facilitate the initiation of female puberty. The results also provide evidence for an involvement of TACE in the process by which glutamatergic neurons communicate with glial cells to activate erbB receptor-mediated signaling and raise the possibility that such a mechanism might be broadly used throughout the brain for neuron-to-glia communication.

\section{References}

Andrews WW, Mizejewski GJ, Ojeda SR (1981) Development of estradiolpositive feedback on luteinizing hormone release in the female rat: a quantitative study. Endocrinology 109:1404-1413.

Apostolakis EM, Garai J, Lohmann JE, Clark JH, O’Malley BW (2000) Epidermal growth factor activates reproductive behavior independent of ovarian steroids in female rodents. Mol Endocrinol 14:1086-1098.

Arribas J, Coodly L, Vollmer P, Kishimoto TK, Rose-John S, Massague J (1996) Diverse cell surface protein ectodomains are shed by a system sensitive to metalloprotease inhibitors. J Biol Chem 271:11376-11382. 
Arribas J, López-Casillas F, Massague J (1997) Role of the juxtamembrane domains of the transforming growth factor- $\alpha$ precursor and the $\beta$-amyloid precursor protein in regulated ectodmain shedding. J Biol Chem 272:17160-17165.

Baselga J, Mendelsohn J, Kim Y-M, Pandiella A (1996) Autocrine regulation of membrane transforming growth factor- $\alpha$ cleavage. J Biol Chem 271:3279-3284.

Berg-von der Emde K, Dees WL, Hiney JK, Hill DF, Dissen GA, Costa ME, Moholt-Siebert M, Ojeda SR (1995) Neurotrophins and the neuroendocrine brain: different neurotrophins sustain anatomically and functionally segregated subsets of hypothalamic dopaminergic neurons. J Neurosci 15:4223-4237.

Bezzi P, Carmignoto G, Pasti L, Vesce S, Rossi D, Rizzini BL, Pozzan T, Volterra A (1998) Prostaglandins stimulate calcium-dependent glutamate release in astrocytes. Nature 391:281-285.

Black RA, Rauch CT, Kozlosky CJ, Peschon JJ, Slack JL, Wolfson MF, Castner BJ, Stocking KL, Reddy P, Srinivasan S, Nelson N, Boiani N, Schooley KA, Gerhart M, Davis R, Fitzner JN, Johnson RS, Paxton RJ, March CJ, Cerretti DP (1997) A metalloproteinase disintegrin that releases tumournecrosis factor-alpha from cells. Nature 385:729-733.

Borrell-Pagès M, Rojo F, Albanell J, Baselga J, Arribas J (2003) TACE is required for the activation of the EGFR by TGF-alpha in tumors. EMBO J 22:1114-1124.

Chao TI, Rickmann M, Wolff JR (2002) The synapse-astrocyte boundary: an anatomical basis for an integrative role in synaptic transmission. In: The tripartite synapse. Glia in synaptic transmission (Volterra A, Magistretti PJ, Haydon PG, eds), pp 3-23. New York: Oxford UP.

Chauvet N, Prieto M, Alonso G (1998) Tanycytes present in the adult rat mediobasal hypothalamus support the regeneration of monoaminergic axons. Exp Neurol 151:1-13.

DeFazio RA, Heger S, Ojeda SR, Moenter SM (2002) Activation of A-type $\gamma$-aminobutyric acid receptors excites gonadotropin-releasing hormone neurons. Mol Endocrinol 16:2872-2891.

Derouiche A, Frotscher M (2001) Peripheral astrocyte processes: monitoring by selective immunostaining for the actin-binding ERM proteins. Glia 36:330-341.

De Seranno S, Estrella C, Loyens A, Cornea A, Ojeda SR, Beauvillain SC, Prevot V (2004) Vascular endothelial cells promote acute ependymoglial cell plasticity. J Neurosci 24:10353-10363.

Doedens JR, Mahimkar RM, Black RA (2003) TACE/ADAM-17 enzymatic activity is increased in response to cellular stimulation. Biochem Biophys Res Commun 308:331-338.

Dong J, Opresko LK, Dempsey PJ, Lauffenburger DA, Coffey RJ, Wiley HS (1999) Metalloprotease-mediated ligand release regulates autocrine signaling through the epidermal growth factor receptor. Proc Natl Acad Sci USA 96:6235-6240.

Dziedzic B, Prevot V, Lomniczi A, Jung H, Cornea A, Ojeda SR (2003) Neuron-to-glia signaling mediated by excitatory amino acid receptors regulates erbB receptor function in astroglial cells of the neuroendocrine brain. J Neurosci 23:915-926.

Eyigor O, Jennes L (1997) Expression of glutamate receptor subunit mRNAs in gonadotropin-releasing hormone neurons during the sexual maturation of the female rat. Neuroendocrinology 66:122-129.

Eyigor O, Jennes L (1998) Identification of kainate-preferring glutamate receptor subunit GluR7 mRNA and protein in the rat median eminence. Brain Res 814:231-235.

Eyigor O, Jennes L (2000) Kainate receptor subunit-positive gonadotropinreleasing hormone neurons express c-Fos during the steroid-induced luteinizing hormone surge in the female rat. Endocrinology 141:779-786.

Galbiati M, Saredi S, Melcangi RC (2003) Steroid hormones and growth factors act in an integrated manner at the levels of hypothalamic astrocytes: a role in the neuroendocrine control of reproduction. Ann NY Acad Sci 1007:162-168.

Galko MJ, Tessier-Lavigne M (2000) Function of an axonal chemoattractant modulated by metalloprotease activity. Science 289:1365-1367.

Garcia-Segura LM, Chowen JA, Naftolin F (1996) Endocrine glia: roles of glial cells in the brain actions of steroid and thyroid hormones and in the regulation of hormone secretion. Front Neuroendocrinol 17:180-211.

Gore AC, Wu TJ, Rosenberg JJ, Roberts JL (1996) Gonadotropin-releasing hormone and NMDA receptor gene expression and colocalization change during puberty in female rats. J Neurosci 16:5281-5289.

Grosche J, Matyash V, Moller T, Verkhratsky A, Reichenbach A, Kettenmann
H (1999) Microdomains for neuron-glia interaction: parallel fiber signaling to Bergmann glial cells. Nat Neurosci 2:139-143.

Gschwind A, Zwick E, Prenzel N, Leserer M, Ullrich A (2001) Cell communication networks: epidermal growth factor receptor transactivation as the paradigm for interreceptor signal transmission. Oncogene 20:1594-1600.

Harano T, Mizuno K (1994) Phorbol ester-induced activation of a membrane-bound candidate pro-transforming growth factor-alpha processing enzyme. J Biol Chem 269:20305-20311.

Hinkle CL, Mohan MJ, Lin P, Yeung N, Rasmussen F, Milla ME, Moss ML (2003) Multiple metalloproteinases process protransforming growth factor-alpha (proTGF-alpha). Biochemistry 42:2127-2136.

Innocenti B, Parpura V, Haydon PG (2000) Imaging extracellular waves of glutamate during calcium signaling in cultured astrocytes. J Neurosci 20:1800-1808.

Jin G, Huang X, Black R, Wolfson M, Rauch C, McGregor H, Ellestad G, Cowling R (2002) A continuous fluorimetric assay for tumor necrosis factor-alpha converting enzyme. Anal Biochem 302:269-275.

Juanes PP, Ferreira L, Montero JC, Arribas J, Pandiella A (2005) N-terminal cleavage of proTGFa occurs at the cell surface by a TACE-independent activity. Biochem J 389:161-172.

Jung H, Shannon EM, Fritschy J-M, Ojeda SR (1997) Several GABA A receptor subunits are expressed in LHRH neurons of juvenile female rats. Brain Res 780:218-229.

Kaczmarek L, Lapinska-Dzwonek J, Szymczak S (2002) Matrix metalloproteinases in the adult brain physiology: a link between c-Fos, AP-1 and remodeling of neuronal connections? EMBO J 21:6643-6648.

Karkkainen I, Rybnikova E, Pelto-Huikko M, Huovila AP (2000) Metalloprotease-disintegrin (ADAM) genes are widely and differentially expressed in the adult CNS. Mol Cell Neurosci 15:547-560.

Kawakami S (2000) Glial and neuronal localization of ionotropic glutamate receptor subunit-immunoreactivities in the median eminence of female rats: GluR2/3 and GluR6/7 colocalize with vimentin, not with glial fibrillary acidic protein (GFAP). Brain Res 858:198-204.

Kiessling LL, Gordon EJ (1998) Transforming the cell surface through proteolysis. Chem Biol 5:R49-R62.

Knowles F (1972) Ependyma of the third ventricle in relation to pituitary function. Prog Brain Res 38:255-270.

Kobayashi H, Wada M, Uemura H (1972) The hypothalamic median eminence as a neuroendocrine organ. Med J Osaka Univ 23:43-55.

Kordon C, Drouva SV, Martínez de la Escalera G, Weiner RI (1994) Role of classic and peptide neuromediators in the neuroendocrine regulation of luteinizing hormone and prolactin. In: The physiology of reproduction, Ed 2, Vol 1 (Knobil E, Neill JD, eds), pp 1621-1681. New York: Raven.

Kozlowski GP, Coates PW (1985) Ependymoneuronal specializations between LHRH fibers and cells of the cerebroventricular system. Cell Tissue Res 242:301-311.

Leighton PA, Mitchell KJ, Goodrich LV, Lu X, Pinson K, Scherz P, Skarnes WC, Tessier-Lavigne M (2001) Defining brain wiring patterns and mechanisms through gene trapping in mice. Nature 410:174-179.

Liu X, Hwang H, Cao L, Buckland M, Cunningham A, Chen J, Chien KR, Graham RM, Zhou M (1998) Domain-specific gene disruption reveals critical regulation of neuregulin signaling by its cytoplasmic tail. Proc Natl Acad Sci USA 95:13024-13029.

Llano E, Pendas AM, Aza-Blanc P, Kornberg TB, Lopez-Otin C (2000) Dm1-MMP, a matrix metalloproteinase from Drosophila with a potential role in extracellular matrix remodeling during neural development. J Biol Chem 275:35978-35985.

Ma YJ, Junier M-P, Costa ME, Ojeda SR (1992) Transforming growth factor alpha (TGF $\alpha$ ) gene expression in the hypothalamus is developmentally regulated and linked to sexual maturation. Neuron 9:657-670.

Ma YJ, Berg-von der Emde K, Moholt-Siebert M, Hill DF, Ojeda SR (1994a) Region-specific regulation of transforming growth factor $\alpha$ (TGF $\alpha$ ) gene expression in astrocytes of the neuroendocrine brain. J Neurosci 14:5644-5651.

Ma YJ, Costa ME, Ojeda SR (1994b) Developmental expression of the genes encoding transforming growth factor alpha (TGF $\alpha$ ) and its receptor in the hypothalamus of female rhesus macaques. Neuroendocrinology 60:346-359.

Ma YJ, Hill DF, Junier M-P, Costa ME, Felder SE, Ojeda SR (1994c) Expression of epidermal growth factor receptor changes in the hypothalamus during the onset of female puberty. Mol Cell Neurosci 5:246-262.

Ma YJ, Hill DF, Creswick KE, Costa ME, Ojeda SR (1999) Neuregulins sig- 
naling via a glial erbB2/erbB4 receptor complex contribute to the neuroendocrine control of mammalian sexual development. J Neurosci 19:9913-9927.

Matthias K, Kirchhoff F, Seifert G, Huttmann K, Matyash M, Kettenmann H, Steinhauser C (2003) Segregated expression of AMPA-type glutamate receptors and glutamate transporters defines distinct astrocyte populations in the mouse hippocampus. J Neurosci 23:1750-1758.

Matute C, Gutierrez-Igarza K, Rio C, Miledi R (1994) Glutamate receptors in astrocytic end-feet. NeuroReport 5:1205-1208.

McFarlane S (2003) Metalloproteases: carving out a role in axon guidance. Neuron 37:559-562.

McKinley MJ, McAllen RM, Mendelsohn FAO, Allen AM, Chai SY, Oldfield BJ (1990) Circumventricular organs: neuroendocrine interfaces between the brain and the hemal milieu. Front Neuroendocrinol 11:91-127.

Montero JC, Yuste L, Diaz-Rodriguez E, Esparis-Ogando A, Pandiella A (2000) Differential shedding of transmembrane neuregulin isoforms by the tumor necrosis factor-alpha-converting enzyme. Mol Cell Neurosci 16:631-648.

Montero JC, Yuste L, Diaz-Rodriguez E, Esparis-Ogando A, Pandiella A (2002) Mitogen-activated protein kinase-dependent and -independent routes control shedding of transmembrane growth factors through multiple secretases. Biochem J 363:211-221.

Negro-Vilar A, Ojeda SR, McCann SM (1979) Catecholaminergic nodulation of LHRH release by median eminence terminals in vitro. Endocrinology 104:1749-1751.

Neumann U, Kubota H, Frei K, Ganu V, Leppert D (2004) Characterization of Mca-Lys-Pro-Leu-Gly-Leu-Dpa-Ala-Arg-NH2, a fluorogenic substrate with increased specificity constants for collagenases and tumor necrosis factor converting enzyme. Anal Biochem 328:166-173.

Ohta S, Harigai M, Tanaka M, Kawaguchi Y, Sugiura T, Takagi K, Fukasawa C, Hara M, Kamatani N (2001) Tumor necrosis factor-alpha (TNFalpha) converting enzyme contributes to production of TNF-alpha in synovial tissues from patients with rheumatoid arthritis. J Rheumatol 28:1756-1763.

Ojeda SR, Ramirez VD (1969) Automatic control of LH and FSH secretion by short feedback circuits in immature rats. Endocrinology 84:786-797.

Ojeda SR, Skinner MK (2005) Puberty in the rat. In: The physiology of reproduction, Ed 3 (Neill JD, ed), pp 2061-2126. San Diego: Academic/Elsevier.

Ojeda SR, Terasawa E (2002) Neuroendocrine regulation of puberty. In: Hormones, brain and behavior, Vol 4 (Pfaff D, Arnold A, Etgen A, Fahrbach S, Moss R, Rubin R, eds), pp 589-659. New York: Elsevier.

Ojeda SR, Urbanski HF (1994) Puberty in the rat. In: The physiology of reproduction, Ed 2, Vol 2 (Knobil E, Neill JD, eds), pp 363-409. New York: Raven.

Ojeda SR, Urbanski HF, Ahmed CE (1986a) The onset of female puberty. Studies in the rat. Rec Prog Horm Res 42:385-442.

Ojeda SR, Urbanski HF, Katz KH, Costa ME (1986b) Activation of estradiol positive feedback at puberty: estradiol sensitizes the LHRH releasing system at two different biochemical steps. Neuroendocrinology 43:259-265.

Ojeda SR, Urbanski HF, Costa ME, Hill DF, Moholt-Siebert M (1990) Involvement of transforming growth factor $\alpha$ in the release of luteinizing hormone-releasing hormone from the developing female hypothalamus. Proc Natl Acad Sci USA 87:9698-9702.

Ojeda SR, Ma YJ, Lee BJ, Prevot V (2000) Glia-to-neuron signaling and the neuroendocrine control of female puberty. Rec Prog Horm Res 55:197-224.

Ojeda SR, Prevot V, Heger S, Lomniczi A, Dziedzic B, Mungenast A (2003) Glia-to-neuron signaling and the neuroendocrine control of female puberty. Ann Med 35:244-255.

Ottem EN, Godwin JG, Petersen SL (2002) Glutamatergic signaling through the $N$-methyl-D-aspartate receptor directly activates medial subpopulations of luteinizing hormone-releasing hormone (LHRH) neurons, but does not appear to mediate the effects of estradiol on LHRH gene expression. Endocrinology 143:4837-4845.

Page RB (1994) The anatomy of the hypothalamo-hypophysial complex. In: The physiology of reproduction, Ed 2 (Knobil E, Neill JD, eds), pp 15271619. New York: Raven.

Pandiella A, Massague J (1991a) Cleavage of the membrane precursor for transforming growth factor a is a regulated process. Proc Natl Acad Sci USA 88:1726-1730.

Pandiella A, Massague J (1991b) Multiple signals activate cleavage of the membrane transforming growth factor- $\alpha$ precursor. J Biol Chem 266:5769-5773.
Peschon JJ, Slack JL, Reddy P, Stocking KL, Sunnarborg SW, Lee DC, Russell WE, Castner BJ, Johnson RS, Fitzner JN, Boyce RW, Nelson N, Koslosky CJ, Wolfson MF, Rauch CT, Cerretti DP, Paxton RJ, March CJ, Black RA (1998) An essential role for ectodomain shedding in mammalian development. Science 282:1281-1284.

Plant TM, Gay VL, Marshall GR, Arslan M (1989) Puberty in monkeys is triggered by chemical stimulation of the hypothalamus. Proc Natl Acad Sci USA 86:2506-2510.

Prenzel N, Zwick E, Daub H, Leserer M, Abraham R, Wallasch C, Ullrich A (1999) EGF receptor transactivation by G-protein receptors requires metalloproteinase cleavage of proHB-EGF. Nature 402:884-888.

Prevot V, Rio C, Cho GJ, Lomniczi A, Heger S, Neville CM, Rosenthal NA, Ojeda SR, Corfas G (2003a) Normal female sexual development requires neuregulin-erbB receptor signaling in hypothalamic astrocytes. J Neurosci 23:230-239.

Prevot V, Cornea A, Mungenast A, Smiley G, Ojeda SR (2003b) Activation of erbB-1 signaling in tanycytes of the median eminence stimulates transforming growth factor $b_{1}$ release via prostaglandin E2 production and induces cell plasticity. J Neurosci 23:10622-10632.

Prevot V, Lomniczi A, Corfas G, Ojeda SR (2005) ErbB-1 and erbB-4 receptors act in concert to facilitate both female sexual development and mature reproductive function. Endocrinology 146:1465-1472.

Rage F, Hill DF, Sena-Esteves M, Breakefield XO, Coffey RJ, Costa ME, McCann SM, Ojeda SR (1997) Targeting transforming growth factor a expression to discrete loci of the neuroendocrine brain induces female sexual precocity. Proc Natl Acad Sci USA 94:2735-2740.

Rio C, Buxbaum JD, Peschon JJ, Corfas G (2002) Tumor necrosis factor- $\alpha$ converting enzyme is required for cleavage of erbB4/HER4. J Biol Chem 275:10379-10387.

Romero C, Paredes A, Dissen GA, Ojeda SR (2002) Nerve growth factor induces the expression of functional FSH receptors in newly formed follicles of the rat ovary. Endocrinology 143:1485-1494.

Rützel H, Schiebler TH (1980) Prenatal and early postnatal development of the glial cells in the median eminence of the rat. Cell Tissue Res 211:117-137.

Sahin U, Weskamp G, Kelly K, Zhou H-M, Higashiyama S, Peshon J, Hartmann D, Saftig P, Blobel CP (2004) Distinct roles for ADAM10 and ADAM17 in ectodomain shedding of six EGFR ligands. J Cell Biol 164:769-779.

Schlöndorff J, Blobel CP (1999) Metalloprotease-disintegrins: modular proteins capable of promoting cell-cell interactions and triggering signals by protein-ectodomain shedding. J Cell Sci 112:3603-3617.

Schlöndorff J, Becherer JD, Blobel CP (2000) Intracellular maturation and localization of the tumour necrosis factor alpha convertase (TACE). Biochem J 347:131-138.

Semyanov A, Kullmann DM (2001) Kainate receptor-dependent axonal depolarization and action potential initiation in interneurons. Nat Neurosci 4:718-723.

Shahab M, Mastronardi C, Seminara SB, Crowley WF, Ojeda SR, Plant TM (2005) Increased hypothalamic GPR54 signaling: a potential mechanism for initiation of puberty in primates. Proc Natl Acad Sci USA 102:2129-2134.

Silverman A-J, Livne I, Witkin JW (1994) The gonadotropin-releasing hormone $(\mathrm{GnRH})$, neuronal systems: immunocytochemistry and in situ hybridization. In: The physiology of reproduction, Ed 2, Vol 1 (Knobil E, Neill JD, eds), pp 1683-1709. New York: Raven.

Simmons DM, Arriza JL, Swanson LW (1989) A complete protocol for in situ hybridization of messenger RNAs in brain and other tissues with radiolabeled single-stranded RNA probes. J Histotechnol 12:169-181.

Steinhäuser C, Gallo V (1996) News on glutamate receptors in glial cells. Trends Neurosci 19:339-345.

Stella N, Tencé M, Glowinski J, Prémont J (1994) Glutamate-evoked release of arachidonic acid from mouse brain astrocytes. J Neurosci 14:568-575.

Topolnik L, Congar P, Lacaille JC (2005) Differential regulation of metabotropic glutamate receptor- and AMPA receptor-mediated dendritic $\mathrm{Ca}^{2+}$ signals by presynaptic and postsynaptic activity in hippocampal interneurons. J Neurosci 25:990-1001.

Urbanski HF, Ojeda SR (1990) A role for N-methyl-D-aspartate (NMDA) receptors in the control of LH secretion and initiation of female puberty. Endocrinology 126:1774-1776.

Záborszky L, Schiebler TH (1978) Über die glia der eminentia mediana. Elektronenmikroskopische untersuchungen an normalen, adrenalektomierten und kastrierten ratten. Z Mikrosk Anat Forsch Leipzig 92:781-799. 